\title{
STUDY OF CORROSION INHIBITION PROPERTIES OF NOVEL SEMICARBAZONES ON MILD STEEL IN ACIDIC SOLUTIONS
}

\author{
DR.RATHIKA.GOVINDASAMY*a , SWETHA AYAPPAN \\ PSG college of Arts and Science, Coimbatore,Tamil Nadu,India.
}

\begin{abstract}
The inhibition efficiency of corrosion on mild steel using acids by three different novel Semicarbazones as inhibitors have been studied using weight loss, potentiodynamic polarization and electrochemical impedance spectroscopy methods. The inhibition efficiency, corrosion rate, the nature of anchoring sites and the adsorption characteristics have been determined from the results. It was found that the newly synthesized compounds behaved as mixed type inhibitors with high inhibition efficiency. The inhibition efficiency increases with increasing the inhibitors concentration but decreases with increasing the temperature. Addition of halide ion enhances the inhibition efficiency. The adsorption of the inhibitors on the mild steel surface obey Langmuir adsorption isotherm.Scanning Electron Spectroscopy is used to examine the surface morphology of mild steel samples both in the presence and absence of inhibitors at optimum conditions. Scanning Electron Microscope reveals the formation of a smooth, dense protective layer in the presence of inhibitor.
\end{abstract}

Key words: Acid solutions; mild steel; 2, 6-diphenylpiperidin-4-one semicarbazones; potentiodynamicPolarisation; Inhibitior ; electro chemical impedence; Scanning Electron Spectroscopy

\section{INTRODUCTION}

Corrosion is the primary means by which metals deteriorate. Most metals corrode in contact with water and also moisture in the air, acids, bases, salts, aggressive metal polishes and other corrosive solids and liquid chemicals. A suitable, effective and economical method has to be adopted depending upon the metal and its environment. Mild steel is of high industrial value. Metals, when subjected to surface treatment such as painting, enameling etc. should have clean surface, free from rust or oxide scales. For removing these rusts and scales, metals are immersed in acid solutions known as acid pickling bath. Generally hydrochloric acid is used in pickling bath. However, now- a- days sulphuric acid has replaced hydrochloric acid as pickling solution due to its economic advantage. Soon after the scales are removed, the acids may attack the metal. To prevent this attack, corrosion inhibitors are generally added to acid solutions. A thorough survey of literature reveals that large number of inorganic and organic compounds have been synthesized and employed as corrosion inhibitors ${ }^{1-6}$. The survey suggests that mild steel corrosion is effectively controlled by the use of organic substances containing nitrogen, oxygen or sulphur in the conjugated system ${ }^{7-9}$.

In the pursuit of a suitable inhibitor for the corrosion of mild steel it was proposed to use 2, 6-diphenylpiperidin-4-one semicarbazone and its derivatives for the present work. Their influences on the corrosion of mild steel have also been investigated.

\section{Experimental}

Mild steel specimens of size $5 \mathrm{~cm} \times 2 \mathrm{~cm} \times 0.05 \mathrm{~cm}$ have been used for weight loss method. Mild steel specimens of same composition with an exposed area of $1 \mathrm{sq} . \mathrm{cm}$ were used for potentiodynamic polarization and AC impedance measurements.

All the three additives (S1, S2 and S3) were preliminarily screened by weight loss method. The metal specimens were initially weighed prior to immersion in $1 \mathrm{M} \mathrm{H}_{2} \mathrm{SO}_{4}$ and $1 \mathrm{M} \mathrm{HCl}$ as corrodant. After a period of 1 hour, the specimens were removed, washed with water, dried and weighed to an accuracy of four decimals. From the initial and final masses of the specimen (before and after immersion in the solution) the loss in weight was calculated. The experiment was repeated for various inhibitor concentrations $(0.5 \mathrm{mM}$ $8 \mathrm{mM}$ ) in $1 \mathrm{M} \mathrm{H}_{2} \mathrm{SO}_{4} 1 \mathrm{M} \mathrm{HCl}$ and $0.5 \mathrm{M} \mathrm{H}_{2} \mathrm{SO}_{4}$

To study the effect of temperature the above procedure was carried out at different temperature ranges $40^{\circ} \mathrm{C}-60^{\circ} \mathrm{C}$ using thermostat. Electrochemical impedance spectroscopy (EIS) and Tafel polarization were conducted in an electrochemical measurement unit (ACM Gill instrument model 903). A platinum foil and $\mathrm{Hg}\left|\mathrm{HgSO}_{4}\right| 1 \mathrm{~N} \mathrm{H}_{2} \mathrm{SO}_{4}$ electrode were used as auxiliary and reference electrode, respectively. Double layer capacitance and charge transfer resistance value were obtained using AC impedance measurements.

\section{Synthesis of Inhibitors}

Synthesis of $\boldsymbol{r}$-2, $\boldsymbol{c}$-6-diphenylpiperidin-4-one semicarbazone(S1)

The method of Balasubramaniam and Padma ${ }^{10}$ was followed for the preparation of the compound $r$-2, $c$-6-diphenylpiperidin-4-one (P1). To the solution of

$r$-2, $c$-6-diphenylpiperidin-4-one ( $1.2 \mathrm{~g}$ in $15 \mathrm{ml}$ ethanol), ethanolic solution of semicarbazide hydrochloride $(0.5 \mathrm{~g})$ and sodium acetate $(0.5 \mathrm{~g})$ were added. The resulting mixture was stirred by use of magnetic stirrer till the precipitate was formed. The product formed was filtered off and washed with water. Crystallization from ethanol gave $62 \%$ yield with an m.pt range of $176-178^{\circ} \mathrm{C}$ (S2)

Synthesis of $r$-2, $c$-6-diphenyl-t-3-ethylpiperidin-4-one semicarbazone

Preparation of $r$-2,c-6-diphenyl-t-3-ethylpiperidin-4-one (P2) was prepared according to the procedure of Noller and Baliah ${ }^{11}$. Ethanolic solution of Semicarbazide hydrochloride $(0.5 \mathrm{~g})$ and sodium acetate $(0.5 \mathrm{~g})$ were added to $r$-2,c-6-diphenyl- $t$-3-ethylpiperidin-4-one( $1.5 \mathrm{~g}$ in ethanol). The contents of the flask were shaken well for 15 minutes and kept at room temperature overnight .The product formed was filtered, washed and recrystallised from ethanol with yield $52 \%$ and $\mathrm{m}$.pt range $184-186^{\circ} \mathrm{C}$

Synthesis of $\quad r$-2, $c$-6-diphenyl-t-3-isopropylpiperidin-4-one semicarbazone (S3)

The procedure given by Noller and Baliah ${ }^{11}$ was followed for the synthesis of $r$-2, $c$-6-diphenyl-t-3-isopropylpiperidin-4-one The method used for the synthesis of $\mathrm{S} 2$ is adopted for the synthesis of $\mathrm{S} 3$ with yield $56 \%$ and m.pt $191-193^{\circ} \mathrm{C}$

\section{CORROSION MONITORING TECHNIQUES USED}

There are basically two general class of corrosion monitoring techniques. They are physio chemical methods and electro chemical methods.

\section{Physiochemical method}

\section{Weight loss method or coupon method}

In this method, the loss of metal due to corrosion is measured by exposing the metal specimen of known area to the environment for a period of time and the difference in weight before and after exposure is calculated.

\section{Experimental procedure}

The initial weight of the polished plate was taken. The solutions were taken in a $100 \mathrm{ml}$ beaker and the specimens were suspended in duplicate into the solution using glass hooks. After a period of one hour, the specimens were removed, washed with water, dried and weighed to an accuracy of four decimals. From the initial and final masses of the specimen (before and after immersion in the solution) the loss in weight was calculated. The experiment was repeated for various inhibitor concentrations in $1 \mathrm{~N} \mathrm{H}_{2} \mathrm{SO}_{4}, 0.5 \mathrm{NH}_{2} \mathrm{SO}_{4}$ and $1 \mathrm{~N}$ HCI. The procedure was repeated for various concentrations of the all the inhibitors prepared. 
The initial weight of the polished plate was taken. The solutions were taken in a $100 \mathrm{ml}$ beaker and the specimens were suspended in duplicate into the solution using glass hooks. After a period of one hour, the specimens were removed, washed with water, dried weighed to an accuracy of four decimals. From the initial and final masses of the specimen (before and after immersion in the solution) the loss in weight was calculated. The experiment was repeated for various inhibitor concentrations in $1 \mathrm{~N} \mathrm{H}_{2} \mathrm{SO}_{4} 0.5 \mathrm{NH}_{2} \mathrm{SO}_{4}$ and $1 \mathrm{~N} \mathrm{HCI}$. The procedure was repeated for various concentrations of the all the inhibitors prepared.

The corrosion rate in mmpy is calculated as follows,

Corrosion rate $(\mathrm{mmpy})=\frac{87.6 \mathrm{X} \text { weight loss }(\mathrm{mg})}{\text { Density }(\mathrm{g} / \mathrm{cc}) \times \text { area }(\mathrm{cm} 2) \times \text { time }(\mathrm{hrs})}$

$1 \mathrm{mpy}=0.0254 \mathrm{~mm} / \mathrm{y}$

Evaluation of efficiency of inhibitor

Inhibitor efficiency has been determined by using the following relationship

$$
\text { I. } E(\%)=\frac{W o-W i}{W i} \times 100
$$

Where $\mathrm{W}_{\mathrm{o}}$ is the weight loss without inhibitor and $\mathrm{W}_{\mathrm{i}}$ is the weight loss with inhibitor.

Evaluation of surface coverage $(\theta)$

$$
\operatorname{surface} \operatorname{coverage}(\theta)=\frac{W b-W i}{\mathrm{~Wb}} \times 100
$$

Where $\mathrm{W}_{\mathrm{b}}$ and $\mathrm{W}_{\mathrm{i}}$ are the weight losses per unit time without and with inhibitor respectively. From this a graph was drawn between $\mathrm{C} / \theta \mathrm{Vs} \mathrm{C}$ or $\mathrm{C} / \theta$ Vs Log C to know whether the adsorption of inhibitor, follows Temkin's / Langmuir isotherm to obtain a linear relationship.

\section{ELECTRO CHEMICAL METHODS}

\section{Galvanostatic or Galvanodynamic test}

Galvanostatic test are conducted with the controlled current instrument. The current is increased at regular intervals or continuously and the resulting specimen potential is measured. This can be done after it has reached a steady state value or it is plotted automatically. This technique is applied for both anodic and cathodic polarization measurements. At about $50 \mathrm{mV}$ from open circuit potential, curves exhibit linear behavior in accordance with the Tafel equation for polarization under activation control.

$$
\eta=\varphi \pm a \ln i / \mathrm{i} 0
$$

Where $\varphi$ - the over voltage, $\mathrm{i}$ - applied current, $\mathrm{i}_{0}$ - the exchange current density at the reversible potential.

\section{Potentiodynamic or potentiostatic polarization method}

Experimentally, the polarization characteristic is measured by plotting the current response as a function of the applied potential. Usually log current function is plotted against potential on a semi log chart. In order to measure and control the potential and current flow of a corroding metal specimen, it is necessary to use a three electrode system via specimen or working electrode, auxiliary electrode and a reference electrode. A typical standard polarization test cell recommended by ASTM-GS could be used for taking the electrolyte and mounting the electrodes. After connecting the electrodes with proper instrument, the potential of the corroding specimen can be changed stepwise at regular intervals or changed continuously at a constant scan rate at fixed temperature ${ }^{17}$. The current that results for each change in potential is recorded. The corrosion rate can be calculated from the following equation,

$$
\text { Corrosion rate }(\mathrm{mmpy})=\frac{0.13 \times \text { icorr } \times \text { E.W }}{\mathrm{d}}
$$

where $\mathrm{i}_{\text {corr }}=$ corrosion current density in $\mathrm{mA} \mathrm{cm}^{2}$. E.W = equivalent weight of corroding specimen in gm. $\mathrm{d}=$ density of the metal in $\mathrm{g} / \mathrm{cm}^{3}$.
Tafel Polarization Method

In this method a plot of E Vs $\log \mathrm{I}$ is made at high over potentials. The rate expression is

$$
i=\frac{\text { icorr }[\exp 2.3 \text { (E-Ecorr)] }}{\beta C}
$$

Taking $\log$ on both sides

$$
\log \mathrm{i}=\frac{\log \text { icorr }+(\mathrm{E}-\mathrm{Ecorr})]}{\beta C}
$$

The plot of $\mathrm{E}$ Vs log i gives a straight line with slope $\beta \mathrm{c}$ and the intercept give $\mathrm{i}_{\text {corr }}$. From $\mathrm{i}_{\text {corr }}$ values, the corrosion rate in mmpy obtained by using the relationship

$$
\text { Corrosion rate }=\frac{3.2 \times i \operatorname{corr}(\mathrm{mA} / \mathrm{cm} 2)}{\mathrm{d}} \times \mathrm{Eq} . \mathrm{Wt}
$$

\section{Linear Polarization Method}

Stem and Geary have shown that there is a linear relationship between current and potential when $\eta=20 \mathrm{mV}$ and on measuring the slope of $\eta$ plot, the corrosion current can be obtained by using the following equation.

$$
\text { icorr }=\frac{\beta \mathrm{a} \times \beta \mathrm{c}}{2.3(\beta \mathrm{a}+\beta \mathrm{c})} \times \frac{1}{\mathrm{dn} / \mathrm{di}}
$$

(Anodic and cathodic reaction activation controlled)

(Anodic reaction activation controlled and cathodic reaction diffusion controlled)

$$
\mathrm{icorr}=\frac{\beta \mathrm{a}}{\mathrm{dn} / \mathrm{di}}
$$

The term $\mathrm{dn} / \mathrm{di}$ has the dimension of resistance. Hence this method is also known as polarization resistance method.

$\beta_{\mathrm{a}}$ - Anodic Tafel slope

$\beta_{c}$ - cathodic Tafel slope

The $i_{\text {corr }}$ is calculated from the above relationship. The value of $\beta_{a}$ and $\beta_{c}$ are obtained from the slopes of the plots of $\eta$ Vs log i.

A.C. Impedence Methods

Alternating current (AC) techniques can provide additional information. Specifically, electrode surface possess an excess surface charge which is balanced by anion accumulation of opposite sign in the adjacent solution, thus making the system electrically neutral. The existence of such a double layer near the electrode surface makes the electrode equivalent to a conventional capacitor and this is the basis of A.C method..

\section{Corrosion Rate}

After calculating $R$ from Nyquist plot and substituting Tafel slope values for cathodic $\beta_{\mathrm{c}}$ and anodic $\beta_{\mathrm{a}}$ in the eqation.

$$
\begin{gathered}
\text { icorr }=\frac{\beta \mathrm{a} \times \boldsymbol{\beta c}}{2.3(\beta \mathrm{a}+\beta \mathrm{c})} \times 1 / \mathrm{Rt} \\
\mathrm{IE}(\%)=\frac{\text { Icorr(o)-Icorr(inh) }}{\operatorname{Icorr}(\mathrm{o})} \times 100
\end{gathered}
$$

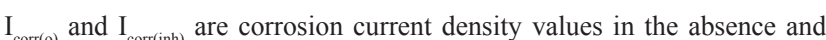
presence of inhibitors respectively ${ }^{20}$.

The corrosion current density of the particular system can be calculated. Thus without disturbing the system much, the corrosion rate can be accurately calculated by A.C. impedance method.

Electrode preparation

Mild steel specimens of size $(5 \mathrm{~cm} \times 2 \mathrm{~cm} \times 0.05 \mathrm{~cm})$ were used. The plates were washed, dried and polished successively using emery sheets of extra coarse, coarse, medium, fine and extra fine grades to remove adhering impurities finally degreased with acetone and dried using a drier. The plates were then kept in a desiccator to avoid the absorption of moisture by the plates.

\section{Calculations}

Potentiodynamic polarization technique

(Tafel polarization method)

Polarization studies were carried out for mild steel to evaluate the corrosion kinetic parameters such as $I_{\text {corr }}, E_{\text {corr }}$ and Tafel slopes $b_{a} \& b_{c}$. 


\section{Electrode}

The mild steel electrodes used for the polarization studies have the same composition as that used for weight loss studies. Cylinders of the mild steel having diameter $1 \mathrm{~mm}$ were embedded in a Teflon holder with an exposed area of 1 sq.cm were used for the present study.

Electrode surface preparation

The mild steel electrode was first cleaned with acid, washed with distilled water and dried. The surface of the electrode was first polished successfully with emery papers. It was then rinsed with distilled water and degreased with acetone. It was thoroughly dried and immediately used for polarization studies.

Electrode cell assembly

The polarization studies were carried out using standard polarization test cells. It consisted of a glass beaker covered with a four hold Teflon top. The biggest hole was used for fitting the mild steel electrode. The smaller hole was used for fitting the reference electrode through lugg-in. The smallest hole was used for fitting the counter electrode. One more hole was provided for purging the inert gas, if needed. The mild steel electrode was then placed in the test solution (uninhibited \& inhibited solutions of 3 different concentrations) for 20-30 minutes before electrochemical measurements.

Electrochemical study

Electrochemical impedance spectroscopy (EIS) and Tafel polarization were conducted in an electrochemical measurement unit (ACM Gill instrument, mode1903). The EIS measurements were made at corrosion potentials over a frequency range of $10 \mathrm{KHz}$ to $0.01 \mathrm{~Hz}$ with single amplitude of $10 \mathrm{mV}$. The Tafel polarization measurements were made after EIS studies for a potential range of $-200 \mathrm{mV}$ to $+200 \mathrm{mV}$ with respect to open circuit potential, at a scan rate of $1 \mathrm{mV}$ per sec. the $\mathrm{I}_{\text {corr }}, \mathrm{E}_{\text {corr }}, \mathrm{R}_{\mathrm{t}}$ and $\mathrm{C}_{\mathrm{dl}}$ values were obtained from the data using the corresponding Corr view and $\mathrm{Z}$ view software's.

The synergistic effect was studied by the addition of $1 \mathrm{mM} \mathrm{KI}$ and $1 \mathrm{mM}$ $\mathrm{H}_{2} \mathrm{SO}_{4}$ containing various concentration of the inhibitors $\mathrm{S} 1, \mathrm{~S} 2$ and $\mathrm{S} 3$ for the duration of 1 hour. From the weight loss the corrosion rate and inhibition efficiency was calculated.

\section{RESULTS AND DISCUSSIONS}

The synthesized compounds (Fig.1) were characterized by elemental analysis (Table 1), IR, NMR and ${ }^{13} \mathrm{C}$ NMR spectral studies. Analysis of the IR spectra of the compounds $\mathrm{S} 1, \mathrm{~S} 2$ and $\mathrm{S} 3$ indicates that all the compounds show two strong bands in the regions $3525-3398 \mathrm{~cm}^{-1}$ and $3400-3367 \mathrm{~cm}^{-1}$ assignable to $v_{\text {am }}(\mathrm{N}-\mathrm{H})$ and $\mathrm{v}_{\mathrm{sym}}(\mathrm{N}-\mathrm{H})$, respectively of the $-\mathrm{N}^{4} \mathrm{H}_{2}$ group of the compounds ${ }^{12,13}$. Another medium intensity broad band around 3319$3306 \mathrm{~cm}^{-1}$ found in the IR spectra of these compounds is due to $-\mathrm{NH}$ stretching vibration involving ring nitrogen. Bands appearing in the region $3100-3030 \mathrm{~cm}^{-}$ ${ }^{1}, 2975-2950 \mathrm{~cm}^{-1}$ and $2898-2850 \mathrm{~cm}^{-1}$ are due to aromatic $\mathrm{v}(\mathrm{C}-\mathrm{H})$, aliphatic and alicyclic $v_{\text {asym }}(\mathrm{C}-\mathrm{H})$ and aliphatic and alicyclic $v_{\mathrm{sym}}(\mathrm{C}-\mathrm{H})$ respectively. A medium to sharp band observed in the region $1568-1492 \mathrm{~cm}^{-1}$ is attributed to $v(\mathrm{C}=\mathrm{N})$ stretching ${ }^{14}$ which indicate the presence of azomethine group in the compound. A strong band in the region $1720-1680 \mathrm{~cm}^{-1}$ is mainly due to $\mathrm{C}=\mathrm{O}$ stretching mode ${ }^{15}$. In addition several other bands in the region $1450-900 \mathrm{~cm}^{-1}$ can be attributed to vibrations involving interactions between $\mathrm{C}=\mathrm{O}$ stretching and C-N stretching (Table 2).

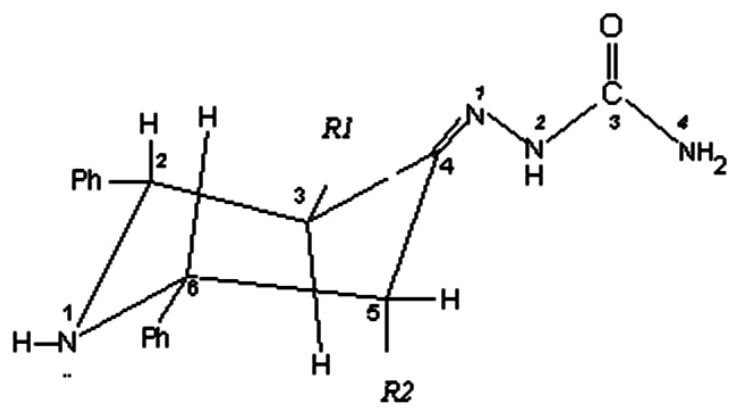

$\begin{array}{ccc}\text { Ligand } & \mathbf{R}^{\mathbf{1}} & \mathbf{R}^{\mathbf{2}} \\ \text { (S1) } & \mathrm{H} & \mathrm{H} \\ (\mathrm{S} 2) & \mathrm{C}_{2} \mathrm{H}_{5} & \mathrm{H} \\ (\mathrm{S} 3) & \mathrm{i}_{-} \mathrm{C}_{3} \mathrm{H}_{7} & \mathrm{H}\end{array}$

Fig 1. Structures of the Compounds S1,S2\&S3.

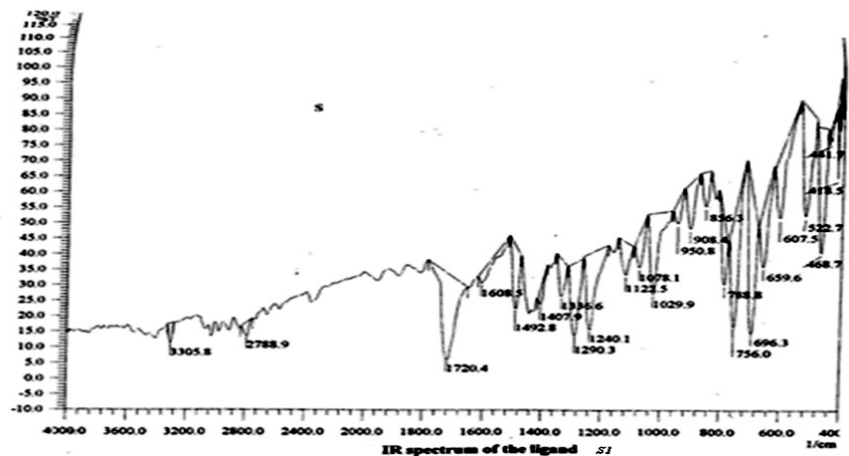

Fig 2. IR Spectra of the ligand S1.

Table 1. Physical and analytical data of 2,-6-diphenylpiperidin-4-one semicarbazones.

\begin{tabular}{|c|c|c|c|c|c|c|}
\hline \multirow{2}{*}{ S.No } & \multirow{2}{*}{$\begin{array}{c}\text { Ligands } \\
\text { Molecular } \\
\text { Formula }\end{array}$} & \multirow{2}{*}{$\begin{array}{l}\text { Melting } \\
\text { point } \\
\left({ }^{\circ} \mathrm{C}\right)\end{array}$} & \multirow{2}{*}{$\begin{array}{c}\text { Yield } \\
(\%)\end{array}$} & \multicolumn{3}{|c|}{ Elements found (calc) } \\
\hline & & & & $\mathrm{C}(\%)$ & H $(\%)$ & N (\%) \\
\hline$\left(\mathrm{S}^{1}\right)$ & $\mathrm{C}_{18} \mathrm{H}_{20} \mathrm{~N}_{4} \mathrm{O}$ & $178-180^{\circ}$ & 65 & $\begin{array}{c}70.20 \\
(70.09)\end{array}$ & $\begin{array}{c}6.29 \\
(6.54)\end{array}$ & $\begin{array}{c}18.01 \\
(18.18)\end{array}$ \\
\hline$\left(\mathrm{S}^{2}\right)$ & $\mathrm{C}_{20} \mathrm{H}_{24} \mathrm{~N}_{4} \mathrm{O}$ & $190-192^{\circ}$ & 70 & $\begin{array}{c}71.22 \\
(71.39)\end{array}$ & $\begin{array}{c}7.03 \\
(7.19)\end{array}$ & $\begin{array}{c}16.52 \\
(16.66)\end{array}$ \\
\hline$\left(\mathrm{S}^{3}\right)$ & $\mathrm{C}_{21} \mathrm{H}_{26} \mathrm{~N}_{4} \mathrm{O}$ & $186-188^{\circ}$ & 65 & $\begin{array}{c}71.39 \\
(71.96)\end{array}$ & $\begin{array}{c}7.62 \\
(7.48)\end{array}$ & $\begin{array}{c}16.04 \\
(15.99)\end{array}$ \\
\hline
\end{tabular}

\section{${ }^{1}$ H NMR Spectral Studies}

The N-H proton of piperidone ring system usually exhibit singlet in the region $2.00-2.07 \mathrm{ppm}{ }^{16}$. The compound $\mathrm{S} 1$ shows a singlet at $2.1 \mathrm{ppm}$ is assignable to $\mathrm{N}-\mathrm{H}$ of piperidin-4-one semicarbazone. All the compounds exhibit a singlet in the region 8.6-8.8ppm is due to $=\mathrm{N}-\mathrm{NH}$ proton. The $-\mathrm{CONH}_{2}$ group of the compounds give two broad signals $\sim 5.3$ and $\sim 6.3 \mathrm{ppm}$. The presence of these broad peaks indicates the two protons are nonequivalent and this may be due to restricted rotation of $-\mathrm{CONH}_{2}$ bond as a result of orientation of semicarbazone group in space. All the compounds show multiplet between 7.24-7.61ppm which is due to aromatic protons (Fig 1b \&Table 3).

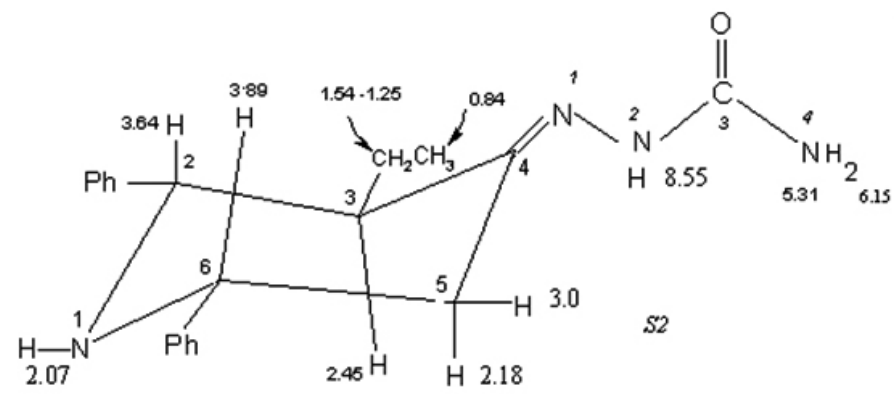

Fig 3. $\mathrm{H}^{1}$ chemical shift data(ppm) S2.

\section{${ }^{13} \mathrm{C}$ NMR Spectral Studies}

The ${ }^{13} \mathrm{C}$ NMR spectral data of the ligands (S1, S2 and S3)are given in the Fig 4 \& Table 4.The signals in the range $150-152.5 \mathrm{ppm}$ is assigned to the azomethine carbon $(\mathrm{C}=\mathrm{N})^{17}$. The signal in the range $126-145 \mathrm{ppm}^{18,19}$ is due to aromatic carbon. The signals of the carbon atom of heterocyclic ring occur in the range $36-69 \mathrm{ppm}$. Thus, IR, ${ }^{1} \mathrm{H}$ NMR Spectral studies and ${ }^{13} \mathrm{C}$ NMR Spectral studies confirm that the ligands (S1, S2 and S3) exist in chair confirmation with alkyl and phenyl groups in equatorial orientation and that they exist in keto form rather than enol form. 
Table-2 Important IR absorption bands of compounds S1, S2 and S3.

\begin{tabular}{|c|c|c|c|c|c|c|}
\hline Compound & $\begin{array}{c}v \\
(\mathbf{C}=\mathbf{O})\end{array}$ & $\begin{array}{c}v \\
\left(\mathbf{N}^{4}-\mathbf{H}\right)\end{array}$ & $\begin{array}{c}v \\
\left(\mathbf{N}^{4} \mathbf{H}\right)_{\text {asym }}\end{array}$ & $\begin{array}{c}v \\
\left(\mathbf{N}^{4}-\mathbf{H}\right)_{\text {symm }}\end{array}$ & $\begin{array}{c}v \\
\left(\mathbf{N}^{2}-\mathbf{H}\right)\end{array}$ & $\begin{array}{c}v \\
(\mathbf{C}=\mathbf{N})\end{array}$ \\
\hline $\mathrm{S} 1$ & $1724 \mathrm{~s}$ & $3306 \mathrm{~s}$ & $3398 \mathrm{~m}$ & $3367 \mathrm{~m}$ & $3085 \mathrm{~m}$ & $1492 \mathrm{~m}$ \\
\hline $\mathrm{S} 2$ & $1682 \mathrm{~s}$ & $3319 \mathrm{~m}$ & $3525 \mathrm{~s}$ & $3406 \mathrm{~s}$ & $3186 \mathrm{~s}$ & $1558 \mathrm{~s}$ \\
\hline $\mathrm{S} 3$ & $1680 \mathrm{~s}$ & $3317 \mathrm{~m}$ & $3525 \mathrm{~s}$ & $3408 \mathrm{~s}$ & $3192 \mathrm{~s}$ & $1555 \mathrm{~s}$ \\
\hline
\end{tabular}

Table 3: ${ }^{1} \mathrm{H}$ NMR Chemical shift data (ppm) S1, S2 and S3.

\begin{tabular}{|c|c|c|c|c|c|c|c|c|c|c|c|}
\hline \multirow{2}{*}{ Ligand } & \multirow{2}{*}{ H-2 } & \multicolumn{2}{|c|}{ H-3 } & \multicolumn{2}{|c|}{ H-5 } & \multirow{2}{*}{ H-6 } & \multirow{2}{*}{$\begin{array}{l}\text { Aromatic } \\
\text { protons }\end{array}$} & \multirow{2}{*}{$\begin{array}{l}\text { Ring } \\
\text { N-H }\end{array}$} & \multirow{2}{*}{$-\mathrm{CONH}_{2}$} & \multirow{2}{*}{$=\mathbf{N N H}$} & \multirow{2}{*}{$\begin{array}{l}\text { Other } \\
\text { protons }\end{array}$} \\
\hline & & $\mathbf{a x}$ & eq & $\mathbf{a x}$ & eq & & & & & & \\
\hline$\left(\mathrm{L}^{1}\right)$ & $\begin{array}{l}3.31 \mathrm{dd} \\
\mathrm{j}=12,3\end{array}$ & $\begin{array}{c}1.93 \\
(\mathrm{dd} \\
\mathrm{J}=14, \\
12)\end{array}$ & $\begin{array}{l}2.52 \\
\text { (b) }\end{array}$ & \multicolumn{2}{|c|}{$2.36-2.42(\mathrm{~m})$} & $\begin{array}{l}3.75, \mathrm{dd} \\
\mathrm{J}=11,3\end{array}$ & $\begin{array}{l}7.2-7.48 \\
(\mathrm{~m}, 10 \mathrm{H})\end{array}$ & $6.2(\mathrm{~b})$ & $\begin{array}{l}5.24 b \\
6.26 b\end{array}$ & $8.85(\mathrm{~s})$ & ------ \\
\hline$\left(\mathrm{L}^{3}\right)$ & $\begin{array}{c}3.64 \\
(J=10)\end{array}$ & \multicolumn{2}{|c|}{$\begin{array}{c}2.45 \\
(\mathrm{t}, \mathrm{J}=11)\end{array}$} & $\begin{array}{c}2.18 \\
(\mathrm{dd}, \mathrm{J}=11.8)\end{array}$ & $\begin{array}{c}3.0 \\
(\mathrm{dd}, \mathrm{J}=13.6 \\
2.9\end{array}$ & $\begin{array}{c}3.9(\mathrm{dd}, \mathrm{J}= \\
11.4,2.4\end{array}$ & $\begin{array}{l}7.24-7.46 \\
(\mathrm{~m}, 10 . \mathrm{H})\end{array}$ & $\begin{array}{c}2.07 \\
(\mathrm{~s})\end{array}$ & $\begin{array}{l}5.34(b) \\
6.15(b)\end{array}$ & $\begin{array}{l}8.55 \\
(\mathrm{~s})\end{array}$ & $\begin{array}{c}1.25,1.54(\mathrm{~m}, 2 \mathrm{H}, \\
\mathrm{c}-3-\mathrm{CH}_{2}-\mathrm{CH}_{3} \\
0.88(\mathrm{t}, 3 \mathrm{~h}, \\
\left.\mathrm{c}-3-\mathrm{CH}_{2}-\mathrm{CH}_{3}\right)\end{array}$ \\
\hline$\left(\mathrm{L}^{4}\right)$ & $\begin{array}{c}3.37 \\
\mathrm{~d}, \mathrm{j}=3,10\end{array}$ & \multicolumn{2}{|c|}{$\begin{array}{c}2.39 \\
(\mathrm{~d}, \mathrm{j}=11)\end{array}$} & $\begin{array}{c}2.06(\mathrm{dd}, \\
\mathrm{J}=14.9 \\
11.5)\end{array}$ & $\begin{array}{c}3.04(\mathrm{dd} \\
\mathrm{J}=11.5,3.2)\end{array}$ & $\begin{array}{c}3.86 \\
(\mathrm{dd}, \mathrm{J}=11 \\
1.7)\end{array}$ & $\begin{array}{c}7.28-7.44 \\
(\mathrm{~m}, 10 \mathrm{H})\end{array}$ & $\begin{array}{c}2.03 \\
(\mathrm{~s})\end{array}$ & $\begin{array}{c}5.42 \\
\text { (b), } 6.1 \\
\text { (b) }\end{array}$ & $\begin{array}{c}8.77 \\
(\mathrm{~s})\end{array}$ & $\begin{array}{c}1.7(\mathrm{~m}, \mathrm{c}-3-\mathrm{c}-3- \\
\mathrm{CH}_{2}-\mathrm{CH}_{3} \\
-\left(2 \mathrm{CH}_{3}\right)\end{array}$ \\
\hline
\end{tabular}

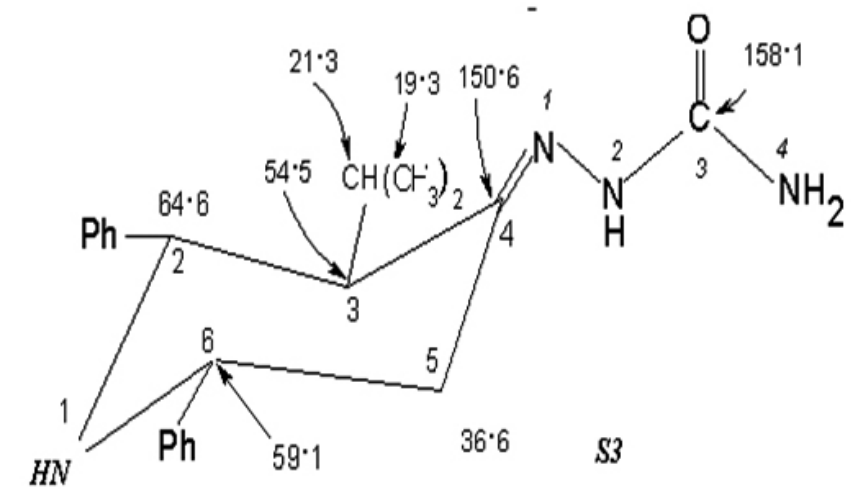

Fig $4{ }^{13} \mathrm{C}$ NMR Chemical shift data (ppm) S3

Table 4: ${ }^{13} \mathrm{C}$ NMR Chemical shift data (ppm) S1, S2 and S3.

\begin{tabular}{|c|c|c|c|c|c|c|c|c|c|c|}
\hline Ligands & $\mathbf{C - 2}$ & $\mathbf{C - 3}$ & $\mathbf{C - 4}$ & $\mathbf{C - 5}$ & $\mathbf{C - 6}$ & $\mathbf{-} \mathbf{C H}_{\mathbf{3}}$ & $\mathbf{-} \mathbf{C H}_{\mathbf{2}}$ & $\mathbf{- C H}$ & $\mathbf{- ( C = \mathbf { O } )}$ & Aromatic carbons \\
\hline$(\mathrm{S} 1)$ & 69.2 & 44.6 & 152.1 & 36.4 & 60.4 & ---- & --- & ---- & 158.4 & $\begin{array}{c}127.2,127.5,127.8, \\
143.9,144.6\end{array}$ \\
\hline$(\mathrm{S} 2)$ & 67.4 & 51.3 & 150.8 & 36.3 & 60.5 & 12.5 & 19.3 & ---- & 158.3 & $\begin{array}{c}126.6,127.3,127.4, \\
128.5,128.6,143.8,144.6\end{array}$ \\
\hline$(\mathrm{S} 3)$ & 64.6 & 54.5 & 150.6 & 36.6 & 59.1 & 19.3 & ---- & 21.3 & 158.1 & $\begin{array}{r}127.2,127.5,127.7,128.4, \\
128.6,128.7144 .7,144.9\end{array}$ \\
\hline
\end{tabular}

\section{Weight loss studies}

The tested piperidin-4-one semicarbazones inhibited the corrosion of mild steel even at low concentration of the acid $\left(1 \mathrm{M} \mathrm{H}_{2} \mathrm{SO}_{4}\right)$ at room temperature. The inhibition efficiency was found to increase with increasing inhibitor concentration. The maximum efficiency of about $88-96 \%$ was obtained at concentrations of $5 \mathrm{mM}-8 \mathrm{mM}$ of inhibitors (Tables 5) and is depicted in Fig.5
It is observed that all the three compounds inhibit the corrosion of mild steel at all concentrations used in this study. A plot of weight loss versus inhibitor concentration (Fig. 6) reveals that the metal loss and corrosion rate (mpy) progressively decreased with increasing inhibitor concentration as is evident from Table 5 
J. Chil. Chem. Soc., 60, No 1 (2015)

Table 5: Inhibition efficiencies, corrosion rate, Degree of coverage of various concentrations of inhibitors (S1, S2 \& S3) for the corrosion of mild steel in1M $\mathrm{H}_{2} \mathrm{SO}_{4}$ obtained by weight loss measurements at room temperature.

\begin{tabular}{|c|c|c|c|c|c|}
\hline $\begin{array}{l}\text { Name of the } \\
\text { inhibitor }\end{array}$ & $\begin{array}{c}\text { Inhibitor } \\
\text { Concen. } \\
(\mathrm{mM})\end{array}$ & $\begin{array}{l}\text { Weight } \\
\text { Loss } \\
\text { (gms) }\end{array}$ & $\begin{array}{c}\text { Inhibition } \\
\text { Efficiency } \\
(\%)\end{array}$ & $\begin{array}{c}\text { Corrosion } \\
\text { Rate } \\
\text { (mpy) }\end{array}$ & Degree of Coverage \\
\hline \multirow{7}{*}{ S1 } & Blank & 0.1375 & & 18826.5 & \\
\hline & 0.5 & 0.0245 & 82.18 & 3354.54 & 0.8218 \\
\hline & 1 & 0.0167 & 87.85 & 2286.56 & 0.8785 \\
\hline & 2 & 0.0121 & 91.2 & 1656.73 & 0.9120 \\
\hline & 3 & 0.0089 & 93.52 & 1218.58 & 0.9352 \\
\hline & 5 & 0.0071 & 94.83 & 972.13 & 0.9483 \\
\hline & 7 & 0.0053 & 96.14 & 725.67 & 0.9614 \\
\hline \multirow{8}{*}{ S2 } & Blank & 0.1463 & & $20,031.39$ & \\
\hline & 0.5 & 0.0472 & 67.73 & 6462.62 & 0.6773 \\
\hline & 1 & 0.0408 & 72.11 & 5586.33 & 0.7211 \\
\hline & 2 & 0.0313 & 78.6 & 4285.59 & 0.7860 \\
\hline & 3 & 0.0353 & 75.8 & 4833.27 & 0.7580 \\
\hline & 5 & 0.0164 & 88.79 & 2245.48 & 0.8879 \\
\hline & 7 & 0.0195 & 86.67 & 2669.94 & 0.8667 \\
\hline & 8 & 0.0184 & 87.23 & 2519.32 & 0.8723 \\
\hline \multirow{9}{*}{ S3 } & Blank & 0.1413 & & $19,346.79$ & \\
\hline & 0.5 & 0.0725 & 48.69 & 9926.70 & 0.4869 \\
\hline & 1 & 0.052 & 63.19 & 7119.84 & 0.6319 \\
\hline & 2 & 0.0414 & 70.70 & 5668.48 & 0.7070 \\
\hline & 3 & 0.0345 & 75.58 & 4723.74 & 0.7558 \\
\hline & 5 & 0.0258 & 81.74 & 3532.53 & 0.8174 \\
\hline & 7 & 0.0127 & 91.01 & 1738.88 & 0.9101 \\
\hline & 8 & 0.0125 & 91.15 & 1711.50 & 0.9115 \\
\hline & 9 & 0.01 & 92.92 & 1369.20 & 0.9292 \\
\hline
\end{tabular}

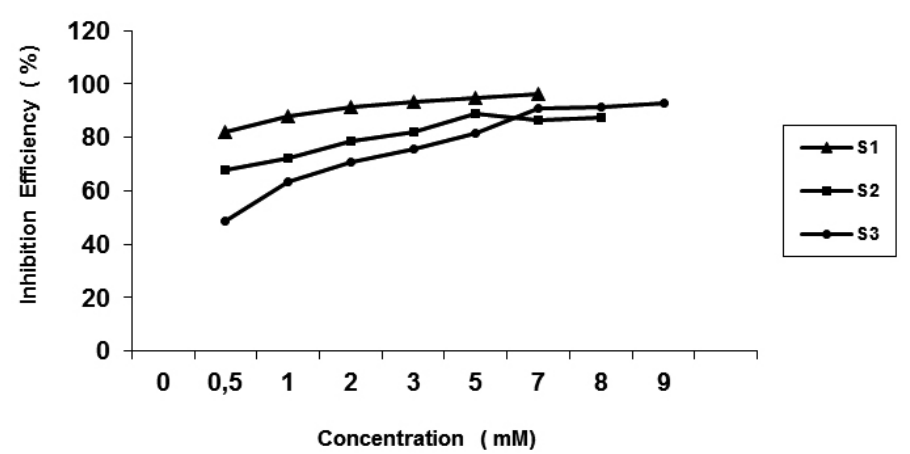

Fig. 5. Variation of inhibition efficiency with concentration of inhibitors at room temperature in $1 \mathrm{M} \mathrm{H}_{2} \mathrm{SO}_{4}$

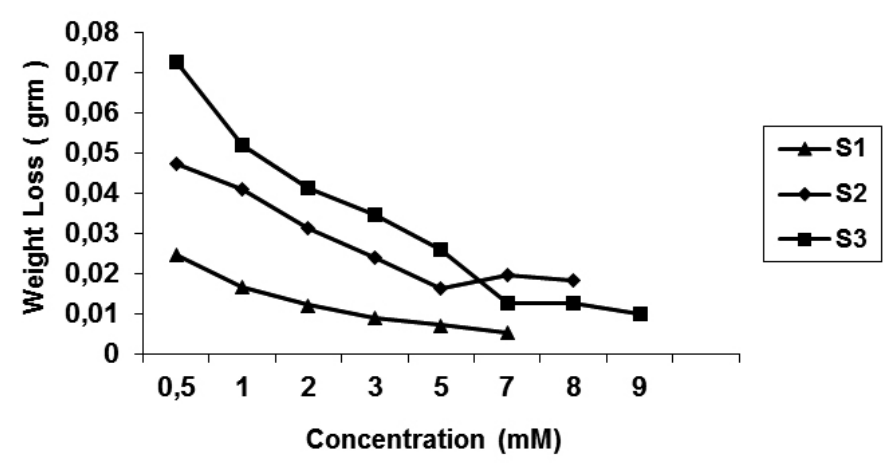

Fig. 6 Plot of Weight loss (gms) Vs concentration (mM) for Inhibition of corrosion of mild steel in $1 \mathrm{M} \mathrm{H}_{2} \mathrm{SO}_{4}$

The corrosion rate in $1 \mathrm{M} \mathrm{H}_{2} \mathrm{SO}_{4}$ for various concentrations of the inhibitors ( $\mathrm{S} 1, \mathrm{~S} 2$ and $\mathrm{S} 3$ ) was determined after 1hour of immersion. The corrosion rate expressed in mpy decreased with increasing inhibitor concentration as evident from Tables 5 and fig (7). 


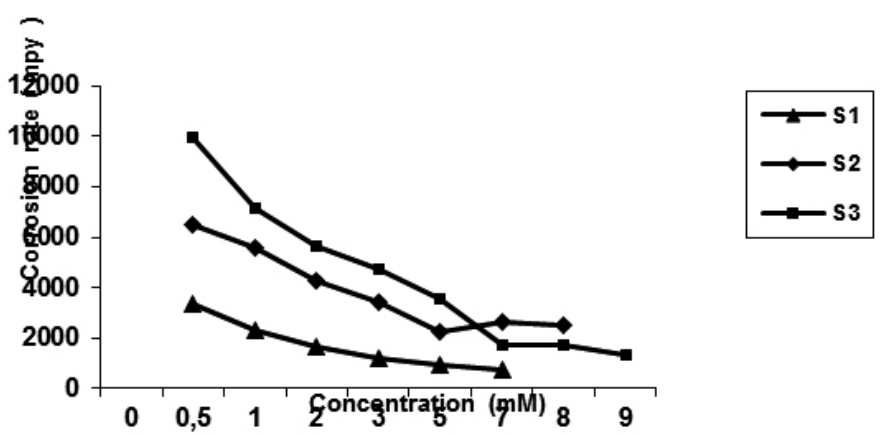

Fig. 7. Variation of Corrosion rate as function of concentration of inhibitors for the corrosion of mid steel in $1 \mathrm{M} \mathrm{H}_{2} \mathrm{SO}_{4}$

\section{Adsorption isotherm]}

The surface coverage $(\theta)$ for different inhibitor concentrations was calculated. The observation of Fig. 8 , a plot of $\mathrm{C} / \theta$ versus $\mathrm{C}$ gives a straight line confirming that all the three inhibitors obeyed Langmuir adsorption isotherm. This result supports the conclusion that maximum inhibition corresponds to the formation of an adsorbed layer of the inhibitor on the active sites of the metal surface.

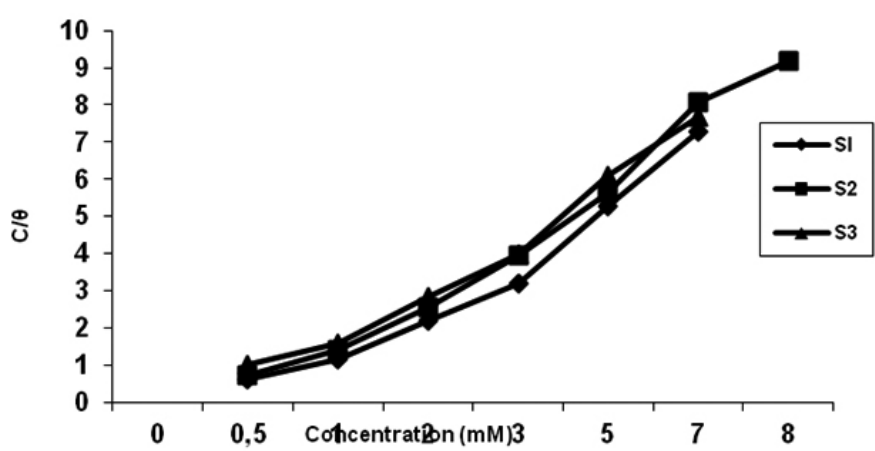

Fig . 8 . Langmuir's Plot of inhibitors in $1 \mathrm{MH}_{2} \mathrm{SO}_{4}$

\section{Influence of Temperature}

It is evident from Table 6 that in $1 \mathrm{M} \mathrm{H}_{2} \mathrm{SO}_{4}$ the dissolution of the metal increases with rise in temperature both in presence and absence of inhibitor. The efficiency of inhibitor decreases with increase in temperature indicating weak adsorption ${ }^{19}$. The decrease in inhibition efficiency with temperature indicates the fact that the inhibitor film formed on the metal surface is less protective in nature at higher temperature ${ }^{20}$.

Table-6 Inhibition efficiencies of $7 \mathrm{mM}$ concentrations of inhibitor ( $\mathrm{S} 1, \mathrm{~S} 2$ and $1 \mathrm{~S} 3$ ) for the corrosion of mild steel in $1 \mathrm{M} \mathrm{H}_{2} \mathrm{SO}_{4}$ obtained by weight loss measurements at higher temperatures.

\begin{tabular}{|c|c|c|c|c|c|}
\hline \multirow{7}{*}{ S1 } & $\begin{array}{l}\text { Temperature } \\
{ }^{\circ} \mathrm{C}\end{array}$ & $\begin{array}{c}\text { Inhibitor } \\
\text { Concentration } \\
\mathrm{mM}\end{array}$ & $\begin{array}{l}\text { Weight } \\
\text { Loss } \\
\text { (gms) }\end{array}$ & $\begin{array}{c}\text { Inhibition } \\
\text { Efficiency } \\
(\%)\end{array}$ & $\begin{array}{l}\text { Corrosion } \\
\text { Rate } \\
\text { (mpy) }\end{array}$ \\
\hline & \multirow{2}{*}{40} & Blank & 0.4085 & & 55931.82 \\
\hline & & 7 & 0.0101 & 97.52 & 1382.89 \\
\hline & \multirow{2}{*}{50} & Blank & 0.6758 & & 92530.53 \\
\hline & & 7 & 0.0258 & 96.18 & 3532.53 \\
\hline & \multirow{2}{*}{60} & Blank & 0.9455 & & 129457.86 \\
\hline & & 7 & 0.1067 & 88.71 & 14609.36 \\
\hline \multirow{6}{*}{ S2 } & 40 & Blank & 0.4706 & & 64434.55 \\
\hline & & 5 & 0.0913 & 80.59 & 12500.79 \\
\hline & 50 & Blank & 0.7216 & & 98801.47 \\
\hline & & 5 & 0.1755 & 75.67 & 24029.46 \\
\hline & 60 & Blank & 1.0530 & & 144176.76 \\
\hline & & 5 & 0.3412 & 67.59 & 46717.10 \\
\hline \multirow{6}{*}{ S3 } & 40 & Blank & 0.4151 & & 56835.49 \\
\hline & & 7 & 0.0388 & 90.65 & 5312.49 \\
\hline & 50 & Blank & 0.6677 & & 91421.48 \\
\hline & & 7 & 0.088 & 86.82 & 12048.90 \\
\hline & 60 & Blank & 0.8711 & & 119271.01 \\
\hline & & 7 & 0.1547 & 82.24 & 21181.52 \\
\hline
\end{tabular}


Activation energy $\left(E_{\mathrm{a}}\right)$ and free energy of adsorption $\left(\Delta G^{0}{ }_{\mathrm{ads}}\right)$ :

The values of activation energy $\left(\mathrm{E}_{\mathrm{a}}\right)$ were calculated from the plot of $\log$ (corrosion rate) Vs 1000/T .Fig. 9

$$
\mathrm{Ea}=\text { slope } \times 8.314 \times 2.303(\mathrm{~J})
$$

The free energy of adsorption $\left(\Delta \mathrm{G}^{0}{ }_{\text {ads }}\right)$ at various temperatures were calculated using the following equation

$$
\Delta \mathrm{G}^{\circ} \text { ads }=-\mathrm{Rt} \ln (5.55 \mathrm{~K})
$$

and the equilibrium constant $\mathrm{K}$ is given by

$$
K=\theta / C(1-\theta)
$$

Where $\theta$ is the degree of coverage on the metal surface, $\mathrm{C}$ is the concentration of inhibitor in $\mathrm{mM}$

The values of $E_{a}$ and $\Delta \mathrm{G}^{0}$ ads are given in Table 7. The less negative values of $\Delta \mathrm{G}^{0}$ ads with increase in temperature indicate the physical adsorption of the inhibitors on the metal surface ${ }^{21}$. The values of $\mathrm{E}_{\mathrm{a}}$ in the inhibited acid solution are appreciably greater than those obtained in the uninhibited acid solution. This suggests that the presence of reactive centers on the inhibitors, block the active sites of corrosion resulting in an increasing in activation energy ${ }^{22}$. This also indicates that these types of indicators are more effective at room temperature, compared to that of higher temperatures ${ }^{23}$.

Table 7. Activation energies $\left(E_{a}\right)$ and free energies of adsorption $\left(\Delta \mathrm{G}_{\text {ads }}^{\circ}\right)$ for the corrosion of mild steel for selected concentrations of the inhibitors in $1 \mathrm{M} \mathrm{H}_{2} \mathrm{SO}_{4}$.

\begin{tabular}{|c|c|c|c|c|}
\hline \multirow{2}{*}{$\begin{array}{c}\text { Name of } \\
\text { the } \\
\text { inhibitors }\end{array}$} & \multirow{2}{*}{$\begin{array}{c}\mathrm{E}_{\mathrm{a}} 40^{\circ} \mathrm{C}- \\
60^{\circ} \mathrm{C} \\
\mathrm{KJ}\end{array}$} & \multicolumn{3}{|c|}{$\Delta \mathrm{G}^{\circ}{ }_{\text {ads }}$ at various temperature (KJ) } \\
\cline { 3 - 5 } & & $40^{\circ} \mathrm{C}$ & $50^{\circ} \mathrm{C}$ & $60^{\circ} \mathrm{C}$ \\
\hline Blank & 38.29 & - & - & - \\
\hline $\mathrm{S} 1$ & 76.58 & -14.943 & -14.2231 & -11.4393 \\
\hline $\mathrm{S} 2$ & 76.58 & -9.9678 & -9.4512 & -8.6980 \\
\hline $\mathrm{S} 3$ & 57.44 & -11.2993 & -10.6223 & -9.9755 \\
\hline
\end{tabular}

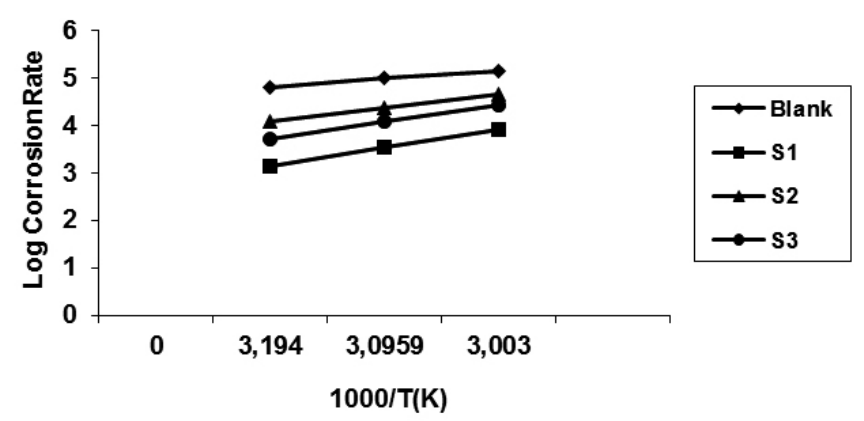

Fig. 9. Arrhenius plot of corrosion rate of mild steel in $1 \mathrm{M} \mathrm{H} 2 \mathrm{SO} 4$ solution in the presence and absence of inhibitor

\section{Electrochemical Studies}

A.C Impedance measurements and potentiodynamicpolarisation studies

A.C Impedance measurements were carried out at room temperature for corrosion of mild steel in $1 \mathrm{M} \mathrm{H}_{2} \mathrm{SO}_{4}$ after immersion for about half an hour. The Nyquist plots for mild steel in uninhibited acid and for the three concentrations of the inhibitors (S1, S2 and S3) as are shown in Fig.11-13 and the data have been tabulated (Table 8). Electrochemical impedance spectroscopy analyses provide insight into the kinetics of electrode processes as well as the surface characteristics of the electrochemical system of interest. The observed increase in the impedance parameters in inhibited solutions is associated with the corrosion inhibiting effect of of the inhibitors S1,S2 and S3. The Nyquist plots for all systems generally have the form of only one depressed semicircle, corresponding to one time constant, although a slight sign of low-frequency inductive behaviour can be discerned. The depression of the capacitance semicircle with centre below the real axis suggests a distribution of the capacitance due to inhomogeneities associated with the electrode surface. The Rct, value can be extracted from the diameter of the semicircle The impedance spectra for the Nyquist plots were thus adequately analyzed by being fit to the equivalent circuit model $\operatorname{Rs}\left(\mathrm{C}_{\mathrm{dl}} \mathrm{R}_{\mathrm{ct}}\right)$, which has been previously used to model the mild steel/acid solution interface Introduction of inhibitors $\mathrm{S} 1, \mathrm{~S} 2, \& \mathrm{~S} 3$ into the acid corrodent leads to an increase in Rct and a reduction of $\mathrm{Cdl}$, indicating a hindering of the corrosion reaction. The decrease in Cdl values, which normally results from a decrease in the dielectric constant and/or an increase in the double layer thickness, is due to inhibitor adsorption on the metal/electrolyte interface This implies that the inhibitors reduce the corrosion rate of the mild steel specimen by virtue of adsorption on the metal/ electrolyte interface, a fact that has been previously established. A quantitative measure of the protective effect can be obtained by comparing the values of the charge transfer resistance in the absence (Rct) and presence of(Rctinh) inhibitor as follows:

$$
\mathrm{IE}(\%)=\left[1-\frac{\text { Rct }}{\text { Rctinh }}\right] \times 100
$$

Where Rct and Rctinh are the charge transfer resistance for inhibited and uninhibited systems, respectively. The values of charge transfer resistance are calculated by the difference of impedance at high and low frequencies on the real axis, as suggested by Haruyama and Tsuru ${ }^{24}$. The capacity $\mathrm{C}$ is determined at the frequency for which the imaginary part of the impedance is maximum $\left(-Z^{\max } i m a g\right)$ from the equation:

$$
f\left(-Z_{\text {imag }}^{\max }\right)=\frac{1}{2 \pi \mathrm{Cdl} \text { Rct }}
$$

The double layer capacitance values of the systems were also examined and calculated using the expression:

$$
C d l=\frac{1}{2 \pi f \max R c t}
$$

Low double layer capacitance suggests reduced electric charge stored, which is a consequence of increased adsorption layer that acted as a dielectric constant. The increase in values in inhibited systems which corresponds to an increase in the diameter of the Nyquist semicircle confirms that the corrosion inhibiting effect of $\mathrm{S} 1, \mathrm{~S} 2 \& \mathrm{~S} 3$ and inhibitors $+\mathrm{KI}$ and is much more pronounced in the latter system, implying that KI synergistically enhanced the corrosion inhibiting effect of inhibitors of S1,S2 \&S3

The Simplified Randles cell is one of most common cell models. It includes a solution resistance, a double layer capacitor and a charge transfer (or polarization resistance). The double-layer capacitance is in parallel with the charge-transfer resistance. In addition to being a useful model in its own right, the Simplified Randles Cell is the starting point for other more complex models. The equivalent circuit for a Simplified Randles Cell is shown in Figure 10 .

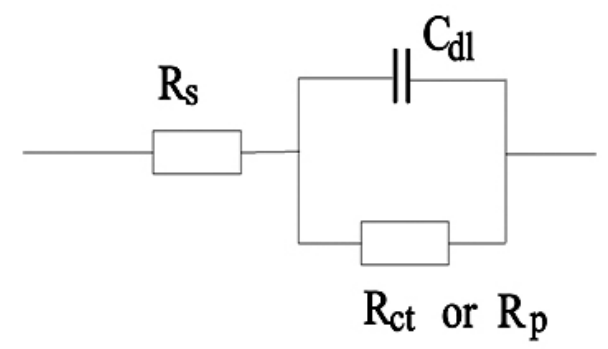

Fig. 10 The suggested equivalent circuit model for the studied system.

The charge transfer resistance $\left(R_{t}\right)$ value for mild steel in uninhibited $\mathrm{H}_{2} \mathrm{SO}_{4}$ significantly changes after the addition of inhibitor. The value of charge transfer resistance increases with increase in concentration. The fact is advocated by the increase in inhibitor efficiency. 
The semicircular nature of Nyquist plots obtained from all experiments indicates that corrosion of mild steel is controlled by charge transfer process as shown in Fig. (11-13).

The double Layer Capacitance $\left(\mathrm{C}_{\mathrm{dl}}\right)$ decreases with increasing inhibitor concentration. The decrease in $\mathrm{C}_{\mathrm{dl}}$ values in presence of inhibitors indicated the fact that these additives inhibit corrosion by adsorption on the metal surface 25,26 .

The various corrosion kinetic parameters such as corrosion current $\left(\mathrm{I}_{\text {corr }}\right)$, corrosion potential $\left(\mathrm{E}_{\text {corr }}\right)$, anodic and cathodic Tafel slopes $\left(\beta_{\mathrm{a}}\right.$ and $\left.\beta_{\mathrm{c}}\right)$ were derived from potentiodynamic polarization studies on mild steel in $1 \mathrm{M} \mathrm{H}_{2} \mathrm{SO}_{4}$ , both in the presence and absence of inhibitors S1,S2 and S3 at different concentrations, Table-9.the polarization curves are depicted in Fig. (14-16). The $\mathrm{E}_{\text {corr }}$ values are shifted slightly in the presence of the inhibitors. The $\mathrm{I}_{\text {cor }}$ value decreases with the addition of inhibitor. Tafel slopes $\beta$ and $\beta$ are affected to the same extent by the addition of inhibitors (S1, S2 and S3),indicating that the inhibitors act as mixed type inhibitors

It is observed that the results of surface coverage in presence of inhibitors (S1, S2 and S3) are in good agreement with those given by weight loss technique. This means that the inhibition efficiency calculated with the help of galvanostatic polarisation technique are nearly equal to the values obtained by weight loss technique.

Table 8 A.C-Impedance parameters for corrosion of mild steel in $1 \mathrm{M} \mathrm{H}_{2} \mathrm{SO}_{4}$ for the selected concentrations of inhibitors (S1, S2 \& $\mathrm{S} 3$ )

\begin{tabular}{|c|c|c|c|c|}
\hline $\begin{array}{l}\text { Name of the } \\
\text { inhibitors }\end{array}$ & $\begin{array}{l}\text { Inhibitorsconcentration } \\
\mathrm{mM}\end{array}$ & $\underset{\mathrm{Ohm} \mathrm{cm}}{\mathrm{R}_{\mathrm{ct}}}$ & $\mathrm{C}_{\mathrm{dl}}$ & $\begin{array}{c}\text { Inhibition } \\
\text { Efficiency }(\%)\end{array}$ \\
\hline \multirow{4}{*}{$\mathrm{S} 1$} & Blank & 2.690 & $2.905 \times 10^{-4}$ & \\
\hline & 2 & 10.92 & $8.265 \times 10^{-5}$ & 81.98 \\
\hline & 5 & 19.79 & $7.432 \times 10^{-5}$ & 91.00 \\
\hline & 7 & 30.56 & $5.171 \times 10^{-5}$ & 92.45 \\
\hline \multirow{4}{*}{$\mathrm{S} 2$} & Blank & 2.690 & $2.905 \times 10^{-4}$ & \\
\hline & 2 & 14.93 & $1.595 \times 10^{-4}$ & 75.36 \\
\hline & 5 & 29.89 & $9.038 \times 10^{-5}$ & 86.40 \\
\hline & 8 & 35.62 & $9.959 \times 10^{-5}$ & 91.19 \\
\hline \multirow{4}{*}{$\mathrm{S} 3$} & Blank & 2.690 & $2.905 \times 10^{-4}$ & \\
\hline & 2 & 12.88 & $9.496 \times 10^{-5}$ & 79.11 \\
\hline & 3 & 27.76 & $8.698 \times 10^{-5}$ & 90.31 \\
\hline & 5 & 28.86 & $6.892 \times 10^{-5}$ & 90.68 \\
\hline
\end{tabular}

Table-9 Corrosion parameters for corrosion of mild steel in $1 \mathrm{MH}_{2} \mathrm{SO}_{4}$ by potentiodynamic polarization method]

\begin{tabular}{|c|c|c|c|c|c|c|}
\hline \multirow{2}{*}{$\begin{array}{l}\text { Name of } \\
\text { the } \\
\text { inhibitors }\end{array}$} & \multirow{2}{*}{$\begin{array}{c}\text { Inhibitor } \\
\text { concentration } \\
\text { mM }\end{array}$} & \multicolumn{2}{|c|}{$\begin{array}{l}\text { Tafel slopes } \\
\mathrm{mV} / \text { decade }\end{array}$} & \multirow{2}{*}{$\begin{array}{l}\mathbf{E}_{\text {corr }} \\
\mathbf{m V}\end{array}$} & \multirow{2}{*}{$\underset{\mathbf{I}}{\mathbf{I A}_{\text {corr }} / \mathbf{c m}^{2}}$} & \multirow{2}{*}{$\begin{array}{c}\text { Inhibitor } \\
\text { Efficiency } \\
\%\end{array}$} \\
\hline & & $\beta_{\mathrm{a}}$ & $\beta_{\mathrm{c}}$ & & & \\
\hline \multirow{4}{*}{$\mathrm{S} 1$} & Blank & 37.0766 & 73.2076 & -472 & 1.34859 & \\
\hline & 2 & 40.3469 & 81.1849 & -481 & 0.01495 & 47.05 \\
\hline & 5 & 80.0441 & 99.4557 & -483 & 0.7140 & 98.89 \\
\hline & 7 & 26.086 & 69.7466 & -469 & 0.2662 & 80.25 \\
\hline \multirow{4}{*}{$\mathrm{S} 2$} & Blank & 37.0766 & 73.2076 & -472 & 1.34859 & \\
\hline & 2 & 46.3751 & 93.0977 & -479 & 0.89812 & 33.403 \\
\hline & 5 & 42.5960 & 88.2886 & -482 & 0.5847 & 56.64 \\
\hline & 8 & 26.2288 & 79.4684 & -471 & 0.3401 & 74.78 \\
\hline \multirow{4}{*}{ S3 } & Blank & 37.0766 & 73.2076 & -472 & 1.34859 & \\
\hline & 2 & 53.1887 & 101.600 & -485 & 0.7868 & 41.65 \\
\hline & 3 & 20.740 & 69.7164 & -464 & 0.2515 & 81.35 \\
\hline & 5 & 34.1767 & 112.062 & -483 & 0.3988 & 70.43 \\
\hline
\end{tabular}




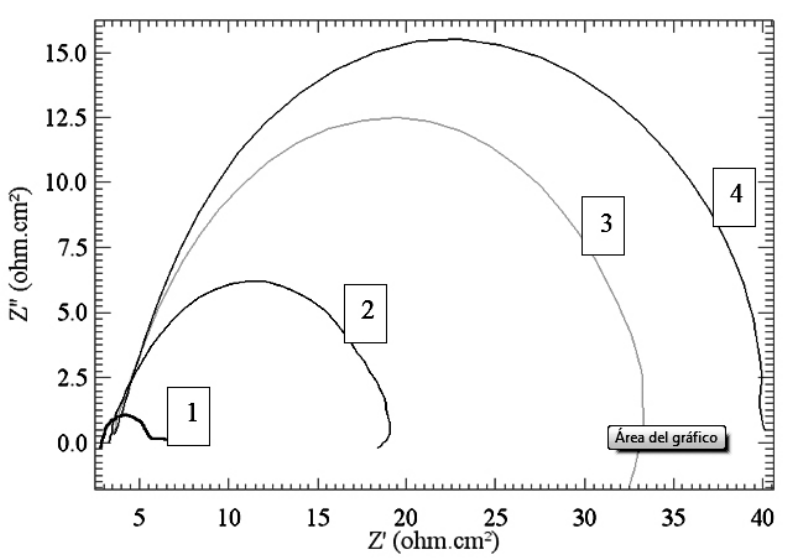

Fig - 11 Nyquist diagrams for mild steel in $1 \mathrm{M} \mathrm{H}_{2} \mathrm{SO}_{4}$ for selected concentration of $\mathrm{S} 1$

$\begin{array}{llll}\text { 1) } 1 \mathrm{M} \mathrm{H}_{2} \mathrm{SO}_{4} & \text { 2) } 1 \mathrm{M} \mathrm{H}_{2} \mathrm{SO}_{4}+2 \mathrm{mMS1} & 3) 1 \mathrm{M} \mathrm{H}_{2} \mathrm{SO}_{4}+5 \mathrm{mMS} 1 & 4)\end{array}$ $1 \mathrm{M} \mathrm{H}_{2} \mathrm{SO}_{4}+7 \mathrm{~m}$

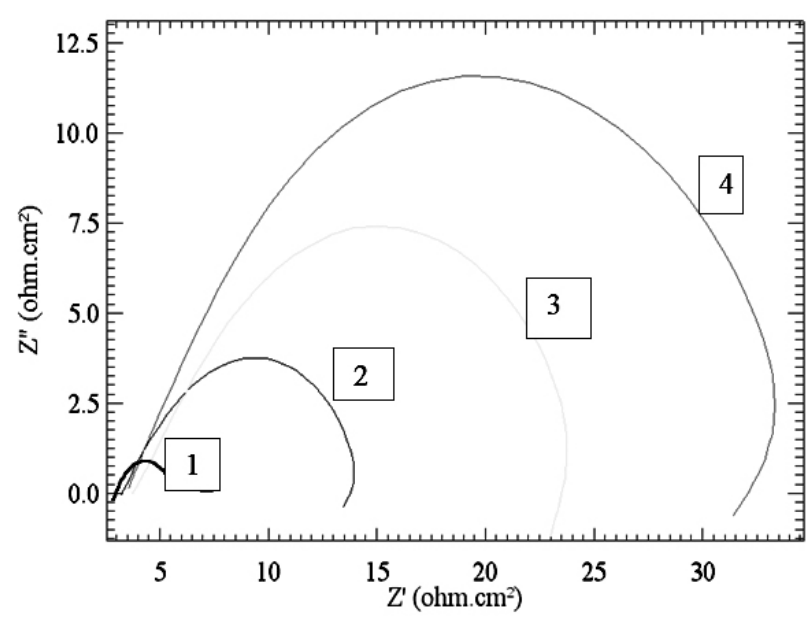

Fig. 12 Nyquist diagrams for mild steel in $1 \mathrm{M} \mathrm{H}_{2} \mathrm{SO}_{4}$ for selected concentration of $\mathrm{S} 2$

1) $1 \mathrm{M} \mathrm{H}_{2} \mathrm{SO}_{4}$ 2) $\left.1 \mathrm{M} \mathrm{H}_{2} \mathrm{SO}_{4}+2 \mathrm{mMS} 23\right) 1 \mathrm{M} \mathrm{H}_{2} \mathrm{SO}_{4}+5 \mathrm{mMS} 2$ 4) $1 \mathrm{M}$ $\mathrm{H}_{2} \mathrm{SO}_{4+} 8 \mathrm{mMS}^{4}$

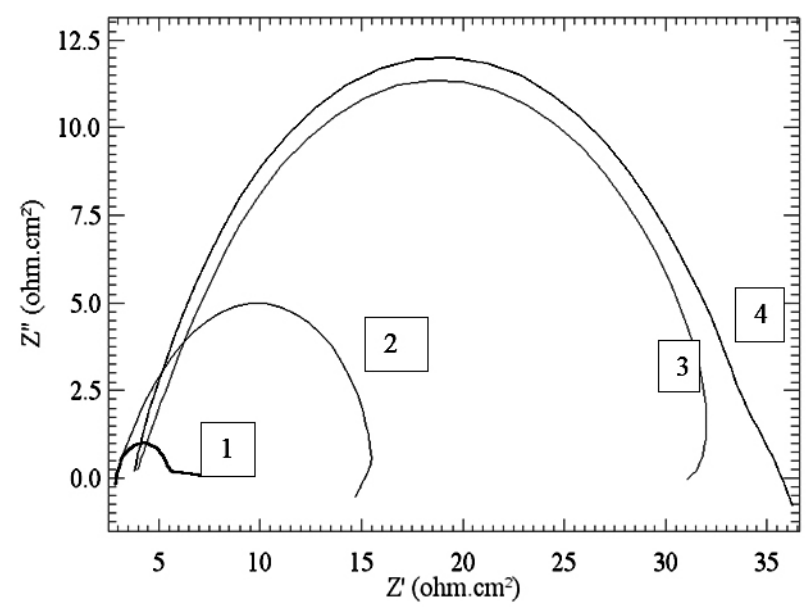

Fig . 13 Nyquist diagrams for mild steel in $1 \mathrm{M} \mathrm{H}_{2} \mathrm{SO}_{4}$ for selected concentration of $\mathrm{S} 3$

1) $1 \mathrm{M} \mathrm{H}_{2} \mathrm{SO}_{4}$ 2) $1 \mathrm{M} \mathrm{H}_{2} \mathrm{SO}_{4}+2 \mathrm{mM} \mathrm{S} 3$ 3) $1 \mathrm{M} \mathrm{H}_{2} \mathrm{SO}_{4}+3 \mathrm{mM} \mathrm{S} 3$ 4) $1 \mathrm{M} \mathrm{H}_{2} \mathrm{SO}_{4}+5 \mathrm{mM} \mathrm{S} 3$

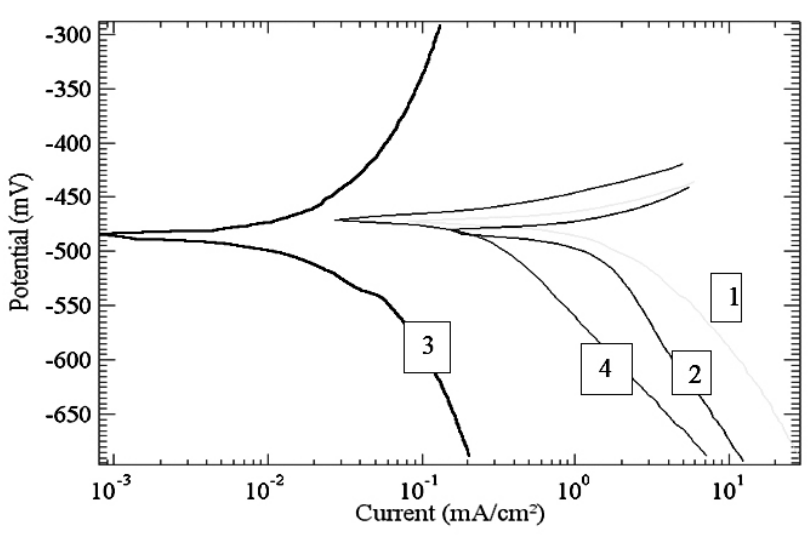

Fig .14 Polarization curves of mild steel recorded in $1 \mathrm{M} \mathrm{H}_{2} \mathrm{SO}_{4}$ for selected concentration of inhibitor $\mathrm{S} 1$

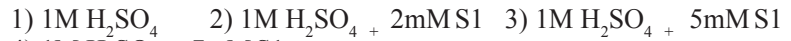

4) $1 \mathrm{M} \mathrm{H}_{2} \mathrm{SO}_{4}+7 \mathrm{mMS1}$

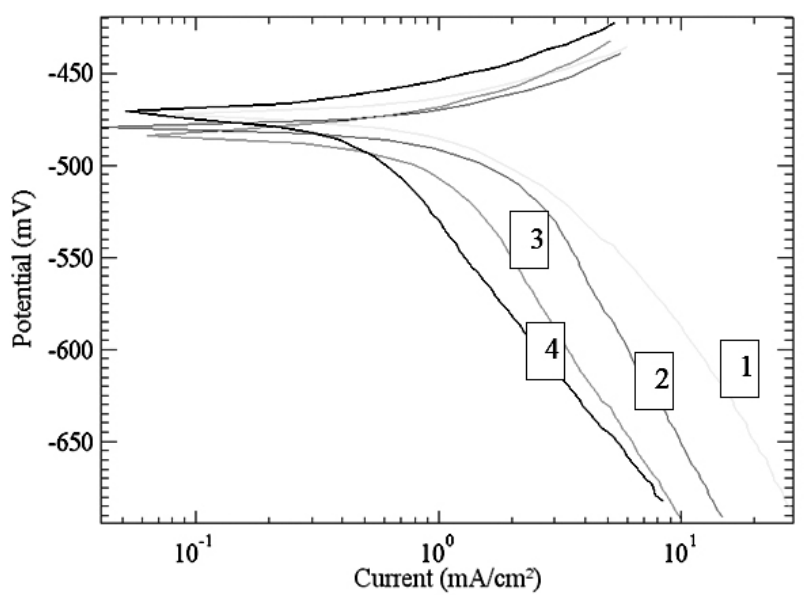

Fig 15 Polarization curves of mild steel recorded in $1 \mathrm{M} \mathrm{H}_{2} \mathrm{SO}_{4}$ for selected concentration of inhibitor $\mathrm{S} 2$

1) $1 \mathrm{M} \mathrm{H}_{2} \mathrm{SO}_{4}$ 2) $1 \mathrm{M} \mathrm{H}_{2} \mathrm{SO}_{4}+2 \mathrm{mMS} 2$ 3) $1 \mathrm{M} \mathrm{H}_{2} \mathrm{SO}_{4}$-5mM S2 4) $1 \mathrm{M}$ $\mathrm{H}_{2} \mathrm{SO}_{4}+8 \mathrm{mMS} 2$

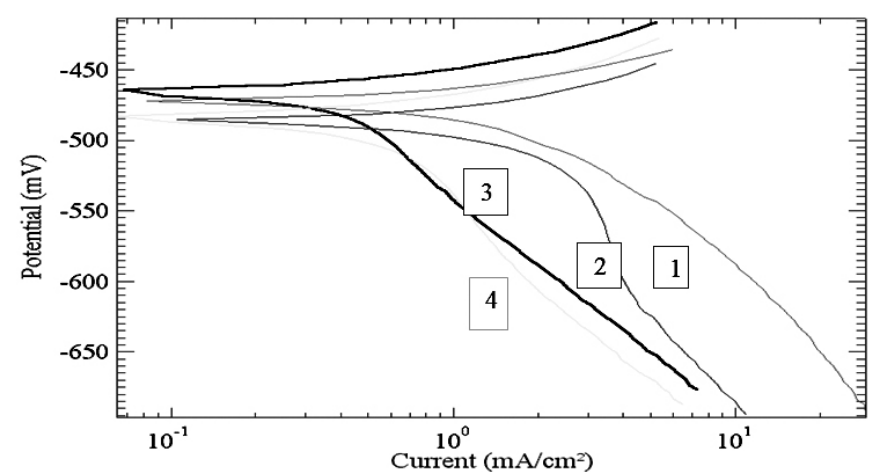

Fig . 16 Polarization curves of mild steel recorded in $1 \mathrm{M} \mathrm{H}_{2} \mathrm{SO}_{4}$ for selected concentration of inhibitor $\mathrm{S} 3$

1) $1 \mathrm{M} \mathrm{H}_{2} \mathrm{SO}_{4}$ 2) $1 \mathrm{M} \mathrm{H}_{2} \mathrm{SO}_{4}+2 \mathrm{mM} \mathrm{S} 3$ 3) $1 \mathrm{M} \mathrm{H}_{2} \mathrm{SO}_{4}+3 \mathrm{mM} \mathrm{S} 3$ 4) $1 \mathrm{M} \mathrm{H}_{2} \mathrm{SO}_{4+} 5 \mathrm{mMS} 3$ 


\section{Synergistic effect}

A comparative study of synergistic effect of corrosion on mild steel in $1 \mathrm{M}$ $\mathrm{H}_{2} \mathrm{SO}_{4}$ by a combination of inhibitors $\mathrm{S} 1, \mathrm{~S} 2$ \& $\mathrm{S} 3$ with and without addition of iodide ions have been studied by weight loss method. The results are given in Table 10 and corrosion inhibition is found to increase with increase in concentration of inhibitors $\mathrm{S} 1, \mathrm{~S} 2$ and $\mathrm{S} 3$. It is evident from the Tables that iodide ions enhance the inhibition of the three inhibitors ${ }^{27,28}$. When I- ions are added to the inhibiting solution, they are chemisorbed by forming chemical bonds on the positively charged steel surface in $1 \mathrm{M} \mathrm{H}_{2} \mathrm{SO}_{4}$. This strong chemisorptions of $\mathrm{I}^{-}$ion shifts the metal to a more positive potential and enhances inhibitor property. The cooperative effect between S1, S2 \& S3 and KI in hindering the corrosion of mild steel in $1.0 \mathrm{MH} 2 \mathrm{SO} 4$ solution is also evident in both the Nyquist and Tafel polarization plots. Addition of KI resulted in a significant increase in the diameter of the Nyquist semicircle and hence an increase in as well as and a decrease in the corrosion current density of the Tafel polarization curves. The presence of iodide ions shifts more in the cathodic direction and further decreases the anodic and cathodic reaction kinetics. The mechanism of this synergistic effect has been described in detail in some reports. The iodide ions are strongly chemisorbed on the corroding mild steel surface and facilitate S1, S2 \& S3 adsorption by acting as intermediate bridges between the positively charged metal surface and inhibitor. This stabilizes the adsorption of S1, S2 \& S3 on the mild steel surface, leading to higher surface coverage. To account for the above observations, it is necessary to recognize that the process of adsorption of an organic inhibitor on a corroding metal surface depends on factors such as the nature and surface charge on the metal in the corrosive medium as well as the inhibitor structure. Consequently, more iodide ions are adsorbed on mild steel which presents a more positive surface, giving rise to increased synergistic interactions and hence higher inhibition efficiencies.

Table-10 Synergistic effect of $1 \mathrm{mM} \mathrm{KI}$ on the inhibition efficiency of S1 ,S2 and S3 by weight loss method at room temperature.

\begin{tabular}{|c|c|c|c|}
\hline \multirow{2}{*}{$\begin{array}{l}\text { Name of the } \\
\text { inhibitor }\end{array}$} & \multirow{2}{*}{$\begin{array}{l}\text { Inhibitor } \\
\text { Concen. } \\
(\mathrm{mM})\end{array}$} & \multicolumn{2}{|c|}{ Inhibitor efficiency $(\%)$} \\
\hline & & Without KI & With 1mM KI \\
\hline \multirow{6}{*}{ S1 } & 0.5 & 82.18 & 91.39 \\
\hline & 1 & 87.85 & 96.93 \\
\hline & 2 & 91.2 & 98.88 \\
\hline & 3 & 93.52 & 99.17 \\
\hline & 5 & 94.83 & 99.42 \\
\hline & 7 & 96.14 & 99.83 \\
\hline \multirow{6}{*}{ S2 } & 0.5 & 67.73 & 72.85 \\
\hline & 1 & 72.11 & 85.07 \\
\hline & 2 & 78.6 & 90.76 \\
\hline & 3 & 75.8 & 94.7 \\
\hline & 5 & 88.79 & 97.66 \\
\hline & 7 & 86.67 & 97.76 \\
\hline \multirow{4}{*}{ S3 } & 0.5 & 48.69 & 68.52 \\
\hline & 1 & 63.19 & 86.69 \\
\hline & 2 & 70.70 & 93.16 \\
\hline & 3 & 75.58 & 95.05 \\
\hline
\end{tabular}

Inhibiting efficiency of the inhibitors in $1 \mathrm{M} \mathrm{HCl}$ and $0.5 \mathrm{M} \mathrm{H}_{2} \mathrm{SO}_{4}$

Weight loss studies were carried out with various concentrations of inhibitors $\mathrm{S} 1, \mathrm{~S} 2$ and $\mathrm{S} 3$ in $1 \mathrm{MHCl}$ (Table 11) and $0.5 \mathrm{M} \mathrm{H}_{2} \mathrm{SO}_{4}$ It is found that inhibition efficiency is maximum in $0.5 \mathrm{M} \mathrm{H}_{2} \mathrm{SO}_{4}$ compared with $1 \mathrm{MHCl}$,for all concentration of inhibitors as is evident from Table 12 . All the compounds inhibit corrosion by adsorption mechanism and adsorption of these compounds follow Langmuir's adsorption isotherm in $1 \mathrm{M} \mathrm{HCl}$ (Fig.17).Variations of inhibition effficiency, weight loss and corrosion rate with concentration were depicted in (Figs.18-20) in 1M HCl.
Table-11 Inhibition efficiency of inhibitor S1, S2 and S3 in $1 \mathrm{M} \mathrm{HCl}$ and $0.5 \mathrm{M} \mathrm{H}_{2} \mathrm{SO}_{4}$

\begin{tabular}{|c|c|c|c|}
\hline \multirow{2}{*}{ Inhibitor } & \multirow{2}{*}{$\begin{array}{l}\text { Inhibitor } \\
\text { Concen. } \\
\text { (mM) }\end{array}$} & \multicolumn{2}{|c|}{ Inhibitor efficiency $(\%)$} \\
\hline & & $0.5 \mathrm{M} \mathrm{H}_{2} \mathrm{SO}_{4}$ & $1 \mathrm{M} \mathrm{HCl}$ \\
\hline \multirow{5}{*}{ S1 } & 0.5 & 73.74 & 68.75 \\
\hline & 1 & 83.94 & 76.38 \\
\hline & 2 & 88.00 & 82.29 \\
\hline & 3 & 91.02 & 84.37 \\
\hline & 5 & 93.29 & 90.62 \\
\hline \multirow{6}{*}{ S2 } & 0.5 & 63.34 & 58.76 \\
\hline & 1 & 74.30 & 61.10 \\
\hline & 2 & 80.47 & 65.87 \\
\hline & 3 & 85.85 & 75.35 \\
\hline & 5 & 88.24 & 86.25 \\
\hline & 7 & 91.93 & 72.51 \\
\hline \multirow{3}{*}{ S3 } & 0.5 & 58.17 & 47.73 \\
\hline & 1 & 66.02 & 67.83 \\
\hline & 2 & 88.75 & 78.64 \\
\hline
\end{tabular}

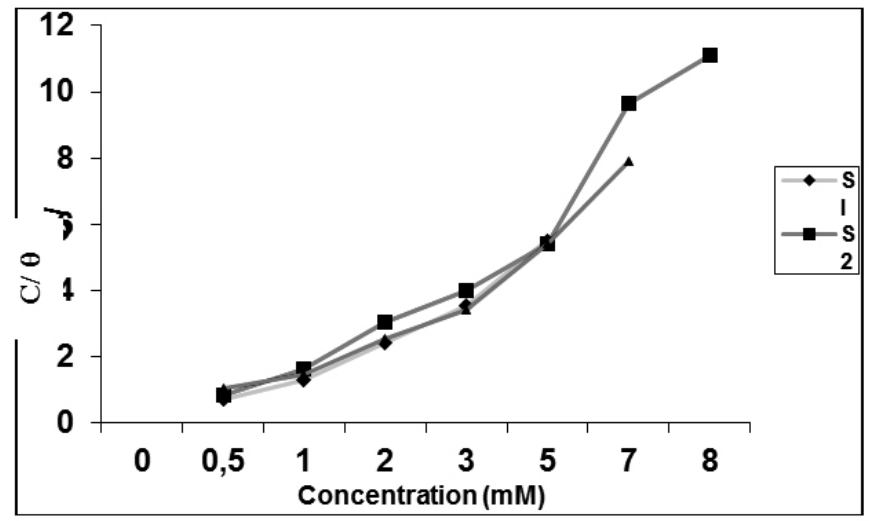

Fig . 17 Langmuir's Plot of inhibitors in 1M HCI

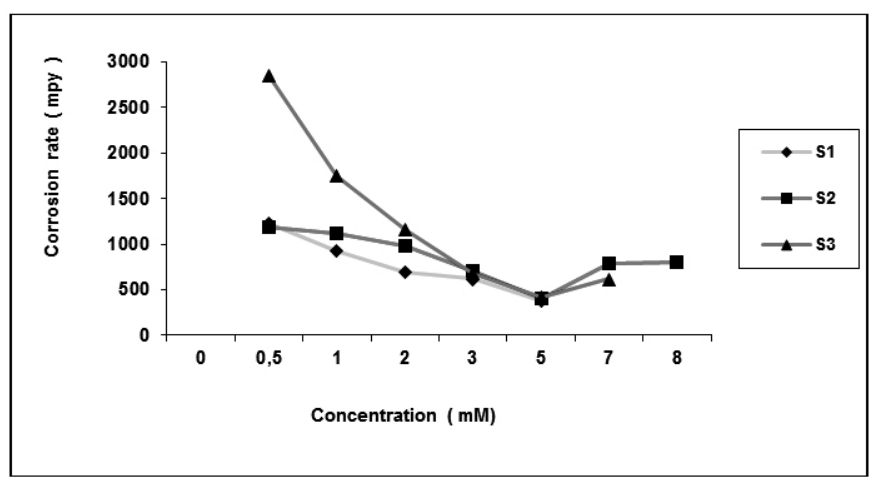

Fig. 18 variation of corrosion rate as an function of concentration of inhibitors for the corrosion of mild steel in $1 \mathrm{M} \mathrm{HCl}$. 


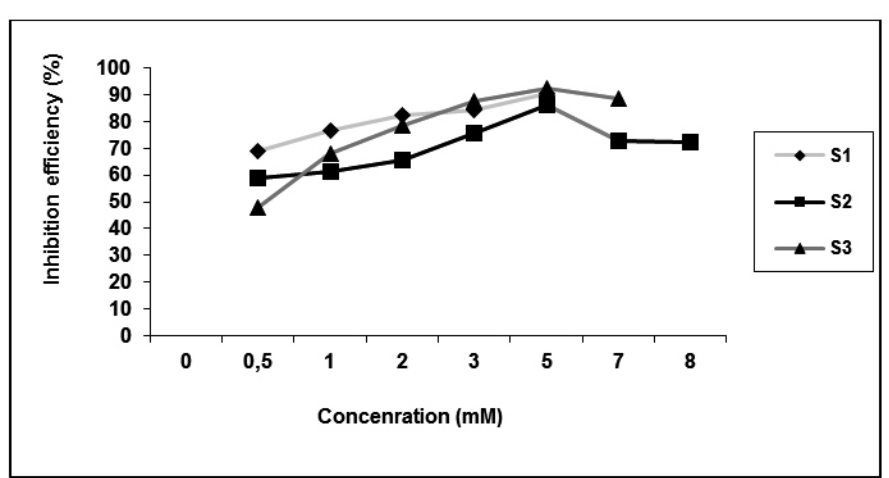

Fig. 19 Variation of inhibitor efficiency with concentration of inhibitors at room t emperature in $1 \mathrm{M} \mathrm{HCI}$

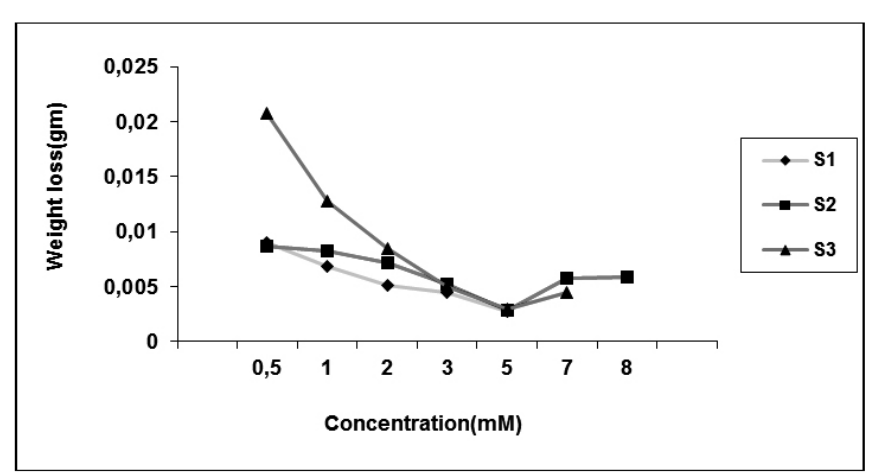

Fig. 20 Plot of Weight loss (gms) Vs concentration (mM) for Inhibition of corrosion of mild steel in $1 \mathrm{M} \mathrm{HCI}$

Table-12 Inhibition efficiencies of various concentrations of inhibitor S1,S2 and S3 for the corrosion of mild steel in $1 \mathrm{M} \mathrm{HCl}$ obtained by weight loss measurements at room temperature

\begin{tabular}{|c|c|c|c|c|c|}
\hline $\begin{array}{l}\text { Name of the } \\
\text { inhibitor }\end{array}$ & $\begin{array}{c}\text { Inhibitor } \\
\text { Concen. } \\
\text { (mM) }\end{array}$ & $\begin{array}{l}\text { Weight } \\
\text { Loss } \\
\text { (gms) }\end{array}$ & $\begin{array}{c}\text { Inhibition } \\
\text { Efficiency } \\
(\%)\end{array}$ & $\begin{array}{c}\text { Corrosion } \\
\text { Rate } \\
\text { (mpy) }\end{array}$ & Degree of Coverage \\
\hline \multirow{6}{*}{ S1 } & Blank & 0.0288 & & 3943.2 & \\
\hline & 0.5 & 0.009 & 68.75 & 1232.2 & 0.6875 \\
\hline & 1 & 0.0068 & 76.38 & 931.05 & 0.7638 \\
\hline & 2 & 0.0051 & 82.29 & 698.29 & 0.8229 \\
\hline & 3 & 0.0045 & 84.37 & 616.14 & 0.8437 \\
\hline & 5 & 0.0027 & 90.62 & 369.68 & 0.9062 \\
\hline \multirow{8}{*}{ S2 } & Blank & 0.0211 & & 2889.01 & \\
\hline & 0.5 & 0.0087 & 58.76 & 1191.20 & 0.5876 \\
\hline & 1 & 0.0082 & 61.1 & 1122.74 & 0.6100 \\
\hline & 2 & 0.0072 & 65.87 & 985.82 & 0.6587 \\
\hline & 3 & 0.0052 & 75.35 & 711.98 & 0.7535 \\
\hline & 5 & 0.0029 & 86.25 & 397.06 & 0.9241 \\
\hline & 7 & 0.0058 & 72.51 & 794.13 & 0.7251 \\
\hline & 8 & 0.0059 & 72.03 & 807.82 & 0.7203 \\
\hline \multirow{7}{*}{ S3 } & Blank & 0.0398 & & 5449.4 & \\
\hline & 0.5 & 0.0208 & 47.73 & 2847.93 & 0.4773 \\
\hline & 1 & 0.0128 & 67.83 & 1752.57 & 0.6783 \\
\hline & 2 & 0.0087 & 78.64 & 1163.82 & 0.7864 \\
\hline & 3 & 0.005 & 87.43 & 684.6 & 0.8743 \\
\hline & 5 & 0.003 & 92.46 & 410.76 & 0.9246 \\
\hline & 7 & 0.0045 & 88.69 & 616.14 & 0.8869 \\
\hline
\end{tabular}

\section{Scanning Electron Microscope (SEM)}

Surface of polished mild steel specimens immersed in $1 \mathrm{M} \mathrm{H}_{2} \mathrm{SO}_{4}$ in the presence and absence of inhibitor S1 was examined using SEM. When a blank determination was conducted, the metal's surface was corroded with etched grain boundaries and other corrosion products were also noticed as seen in the Fig.21. The micrograph reveals that the surface is strongly damaged in the absence of inhibitor (active corrosion). But in the presence of inhibitors, the micrograph reveals that there is decrease in the corrosion sites and pits over the surface of the mild steel (Fig.22). This is due to the formation of adsorption layer of inhibitor on the metal surface. 


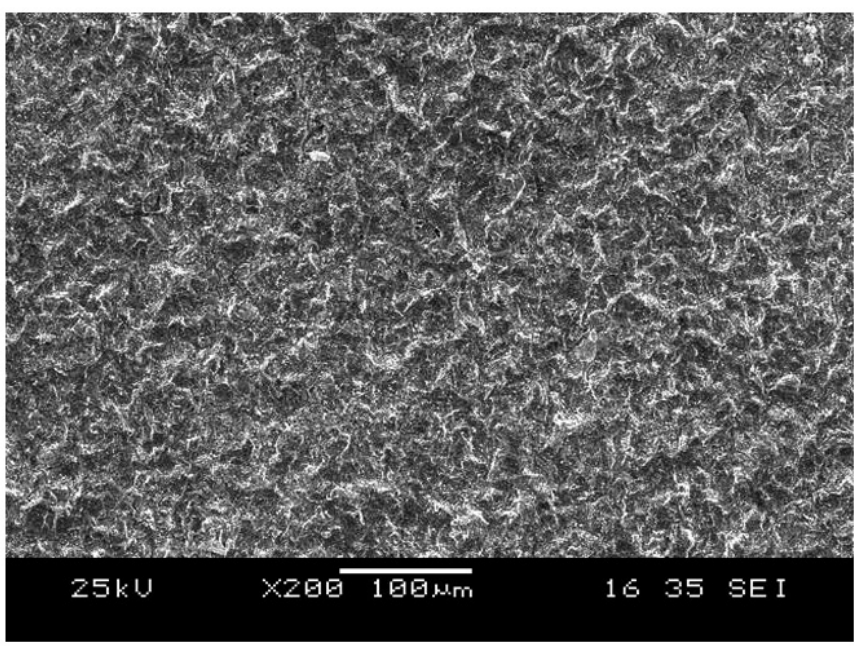

Fig. 21 scanning electron micrograph of mild steel sample after immersion in $1 \mathrm{M} \mathrm{H}_{2} \mathrm{SO}$

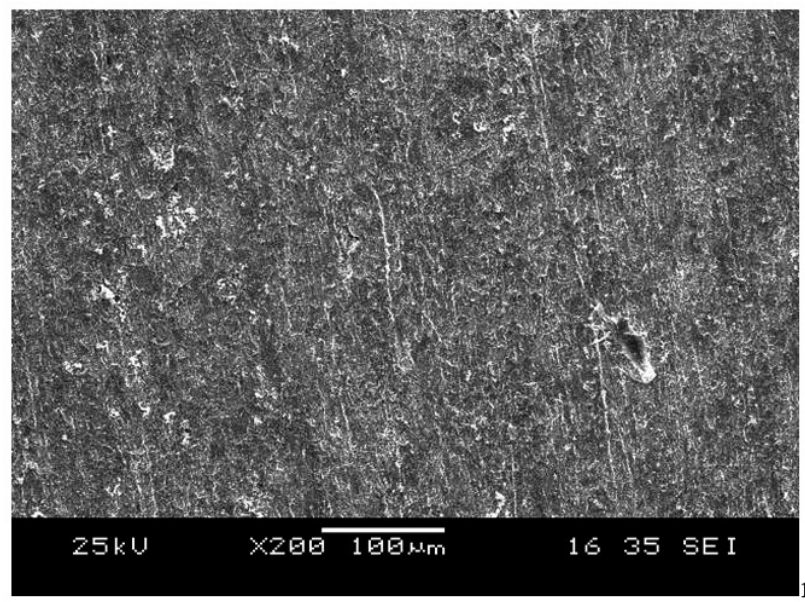

Fig. 22 Scanning electron micrograph of mild steel sample after immersion in $1 \mathrm{M} \mathrm{H}_{2} \mathrm{SO}_{4}$ in presence of ppm of inhibitors.

From these observations we can say that the inhibitor gives a good inhibition effect for the mild steel and thus confirms the results obtained from other techniques.

\section{CONCLUSION}

The extent of these adsorption of different inhibitors at a fixed concentration would depends upon, the surface area of the inhibitor molecules, the number of active centers such as N,S,O atoms and the intensities of lone pairs of electrons on these sites along with the intensities of $\pi$ electrons on aromatic rings. It is well known that iron has coordinating affinity toward, nitrogen, sulphur and oxygen-bearing ligands .Hence, adsorption on iron can be attributed to coordination through $-\mathrm{NH}-\mathrm{CO}$-group, $-\mathrm{C}=\mathrm{N}$ and $-\mathrm{NH}_{2}$ hetero atom ( $\mathrm{N}$ and $\mathrm{O}$ ), and pi-electrons of aromatic ring. ${ }^{29-33}$

The percentage inhibition efficiency exhibited by these inhibitors is high and supposed to be due to strong adsorption of the inhibitors on the metal surface thereby preventing corrosion of mild steel in acid solutions. The inhibition efficiency of piperidin-4-one semicarbazones (S1, S2 and S3) are expected to adsorbed through the lone pairs of electrons on $\mathrm{N}$ and $\mathrm{O}$ atoms as well as $\pi$ electron density on the phenyl ring by their coordination with the metal surface.

The inhibitors Among the compounds investigated in the present study the order of IE has been found as $\mathrm{S} 1>\mathrm{S} 2>\mathrm{S} 3$
The inhibition of active dissolution of the metal is due to the adsorption of the inhibitor molecules on the metal surface forming a protective film. The inhibitor molecules can be adsorbed onto the metal surface through electron transfer from the adsorbed species to the vacant electron orbital of low energy in the metal to form a co-ordinate type link

The three compounds were found to inhibit the corrosion of mild steel in $1 \mathrm{M} \mathrm{H}_{2} \mathrm{SO}_{4}$ and $1 \mathrm{M} \mathrm{HCl}$ by forming an insoluble protective layer on the surface.

The following conclusions can be drawn on the basis of the present investigation.

- Piperidin -4- one semicarbazones are effective inhibitors for corrosion of mild steel in $1 \mathrm{M} \mathrm{H}_{2} \mathrm{SO}_{4}$ at optimum concentration of $(5 \mathrm{mM}-8 \mathrm{mM})$.

- The inhibition efficiency increases with increasing inhibitor concentration.

- All the compounds inhibit corrosion by adsorption mechanism and adsorption of these compounds from acid solution follow Langmuir's adsorption isotherm.

- Higher values of thermodynamic activation function (Ea) for inhibited system than those for uninhibited acids show the temperature dependence on inhibition efficiency.

- The negative $\Delta \mathrm{G}^{\mathrm{o}}$ values indicate the spontaneous adsorption of the inhibitors on the surface of mild steel.

- Electrochemical impedance spectroscopy experiments have shown that an increase in inhibitor concentration causes an increase in polarization resistance $\mathrm{Rc}_{\mathrm{t}}$. where as a decrease in $\mathrm{C}_{\mathrm{dl}}$ values, is due to the increase in thickness of the adsorbed layer.

- The Tafel slopes obtained from potentiodynamic polarization curves indicate that all the compounds behave as mixed type inhibitors with more cathodic character in $1 \mathrm{M} \mathrm{H}_{2} \mathrm{SO}_{4}$.

- Addition of halide ions enhances inhibition efficiency.

- It can be noted that S1, S2 and S3's inhibition performance is better in $\mathrm{H}_{2} \mathrm{SO}_{4}$ than in $\mathrm{HCl}$.

- Scanning Electron Microscope reveals the formation of a smooth, dense protective layer in the presence of inhibitor.

\section{REFERENCE}

1. Tuken, T; Turk. J.Chem. 2002, 26,735.

2. Quraishi M.A; Materials chemistry and physics. 2003.,77,43

3. Mirghasem Hosseini; Stijn F.L.Mertens; Mohammed R Arshadi; Corrosion Science. 2003, 45(7), 1473.

4. Quraishi.M.A; Indian.J.Chem., Technol. 2005, 11,220.

5. Lebrini.M; Lagrenee.M; Vezin.H; Gengembre.L; Bentiss.F; Corrosion Science. 2005, 47(2),485.

6. Yu.I.Kuznetsov; Int. J. Corros. Scale Inhib., 2012, 1, no. 1, 3-15.

7. A. Zarrouk , H. Zarrok, R. Salghi, B. Hammouti, F. Bentiss,R. Touir, M. Bouachrine 5 J. Mater. Environ. Sci. 4 (2), 2013 ,177-192

8. Noor.E.A; Corrosion Science. 2005, 47, 33.

9. Essoufi.H; Kertit.S; Hammouti.B; Benkddour.M; Bull.Electrochem. 2000, 16(5),205.

10. Balasubramanian.M , Padma.N; Tetrahedron. 1963, 19,2135.

11. Noller.C.R; Baliah.V; J.Am.Chem.Soc.1948, 70, 3853.

12. Iskander.M.F; Sayed.L.E.I; Saleem.N.M.H; Haase.W; Linder.H.J; Foro.S; Polyhedron. 2004, 23, 23.

13. Chandra.S; Gupta.L.K; Spectrochimica Acta Part A. 2005, 61, 2549.

14. Afrasiabi.Z; Sinn.E; Lin.E; Ma.Y; Campana.C; Pandye.S; J. Inorg, Bioche., 2005, 99, 156.

15. Basudi.F; Peng.S.M ; Bhattacharya.S; Inorg. Chem. 2000, 139, 1120

16. Selvaraj.K; Theivarasu.C; Synth. React. Inorg.Met-Org.Chem. 2003, 30(6), 113.

17. Raman.N; Esthar .S; Thangaraja.C; J.Chem.Science. 2004, 116(4),209.

18. Agarwal.N; Mishra.P; J.Zhejiang.,Univ.Sci. 2005, 6B (7) 617.

19. Jha.G.S; Prasad.D; Chaudhry.B.P; Sanyal.S; J. Ind. Chem. Soc. 2000, 77,166 .

20. Quraishi.M.A; Wajid Khan.M; Ajmal.M; Muralidharan.S; Iyer.S.V.K;

Anti Corrosion Methods and Materials. 1996, 43, 5.

21. Abdel-AAI.M.S; Morad.M.S; Br. Corros.J., 2001, 36, 253.

22. Putilova.I.M; Balezin.S.A; Baranik.U.P; Metallic corrosion inhibitors. Pergmon Press, New York, 1960, 31.

23. Quaraism; Rawat.J; Ajmal.M; Corr.1998, 54, 996.

24.Tsuru. T, Haruyama.S, Gijutsu. B, Jpn. J .Soc. Corros. Eng. 1978,27,573.

25. Hosseini.M.G; Ehteshamzadeh .M; Shahrabi.T; Electrochem, Acta. 2007, 52, 3680 . 
26. Guannan Mu; Zueming Li; Guanheng Liu; Corrosion Science. 2005, 47, 1932 .

27. Fouda.A.S; Mostafa. H.A; El -Taib.F; Elewady.G.Y; Corrosion Science. 2005, 47, 1998.

28. Kaleid.K.F; Babic - Samarazija.K; Hackerman.N, J. Appl. Electrochem.2004, 34, 697

29. Stanly Jacob.K and Geetha Parameswaran, Corros Sci 2010, 52: 224228
30. Muralidharan, R. Chandrasekar and S.V.K. Iyer,. Proc.Indian Acad. Sci (Chem. Sci) 2000 112: 127-136

31. Ramesh Saliyan .V and Airody Vasudeva Adhikari,. Indian J Chem Technol 2009, 16: 162

32. Singh .A.K and Quraishi. M. A. J Appl Electrochem 201040: 1293-1306

33. Abd El-Maksoud. S. A.. A review. Int J Electrochem Sci 2008, 3: 528-555 